\title{
The direct and indirect radiative effects of biogenic secondary organic aerosol
}

\author{
C. E. Scott ${ }^{1}$, A. Rap ${ }^{1}$, D. V. Spracklen ${ }^{1}$, P. M. Forster ${ }^{1}$, K. S. Carslaw ${ }^{1}$, G. W. Mann ${ }^{1,2}$, K. J. Pringle ${ }^{1}$, N. Kivekäs ${ }^{3}$, \\ M. Kulmala ${ }^{4}$, H. Lihavainen ${ }^{3}$, and P. Tunved ${ }^{5}$ \\ ${ }^{1}$ School of Earth and Environment, University of Leeds, Leeds, LS2 9JT, UK \\ ${ }^{2}$ National Centre for Atmospheric Science, University of Leeds, Leeds, LS2 9JT, UK \\ ${ }^{3}$ Finnish Meteorological Institute, Erik Palmenin aukio 1, 00560 Helsinki, Finland \\ ${ }^{4}$ Department of Physics, University of Helsinki, P.O. Box 64, 00014, Finland \\ ${ }^{5}$ Department of Applied Environmental Research, Stockholm University, Svante Arrhenius Väg 8c, \\ 10691 Stockholm, Sweden
}

Correspondence to: C. E. Scott (c.e.scott@leeds.ac.uk)

Received: 13 May 2013 - Published in Atmos. Chem. Phys. Discuss.: 26 June 2013

Revised: 1 November 2013 - Accepted: 3 December 2013 - Published: 14 January 2014

\begin{abstract}
We use a global aerosol microphysics model in combination with an offline radiative transfer model to quantify the radiative effect of biogenic secondary organic aerosol (SOA) in the present-day atmosphere. Through its role in particle growth and ageing, the presence of biogenic SOA increases the global annual mean concentration of cloud condensation nuclei $(\mathrm{CCN}$; at $0.2 \%$ supersaturation) by 3.6-21.1\%, depending upon the yield of SOA production from biogenic volatile organic compounds (BVOCs), and the nature and treatment of concurrent primary carbonaceous emissions. This increase in $\mathrm{CCN}$ causes a rise in global annual mean cloud droplet number concentration (CDNC) of $1.9-5.2 \%$, and a global mean first aerosol indirect effect (AIE) of between $+0.01 \mathrm{~W} \mathrm{~m}^{-2}$ and $-0.12 \mathrm{~W} \mathrm{~m}^{-2}$. The radiative impact of biogenic SOA is far greater when biogenic oxidation products also contribute to the very early stages of new particle formation; using two organically mediated mechanisms for new particle formation, we simulate global annual mean first AIEs of $-0.22 \mathrm{~W} \mathrm{~m}^{-2}$ and $-0.77 \mathrm{~W} \mathrm{~m}^{-2}$. The inclusion of biogenic SOA substantially improves the simulated seasonal cycle in the concentration of CCN-sized particles observed at three forested sites. The best correlation is found when the organically mediated nucleation mechanisms are applied, suggesting that the first AIE of biogenic SOA could be as large as $-0.77 \mathrm{~W} \mathrm{~m}^{-2}$. The radiative impact of SOA is sensitive to the presence of anthropogenic emissions. Lower background aerosol concentrations simu-
\end{abstract}

lated with anthropogenic emissions from 1750 give rise to a greater fractional $\mathrm{CCN}$ increase and a more substantial first AIE from biogenic SOA. Consequently, the anthropogenic indirect radiative forcing between 1750 and the present day is sensitive to assumptions about the amount and role of biogenic SOA. We also calculate an annual global mean direct radiative effect of between $-0.08 \mathrm{~W} \mathrm{~m}^{-2}$ and $-0.78 \mathrm{~W} \mathrm{~m}^{-2}$ in the present day, with uncertainty in the amount of SOA produced from the oxidation of BVOCs accounting for most of this range.

\section{Introduction}

Vegetation emits biogenic volatile organic compounds (BVOCs), such as monoterpenes $\left(\mathrm{C}_{10} \mathrm{H}_{16}\right)$ and isoprene $\left(\mathrm{C}_{5} \mathrm{H}_{8}\right)$, into the atmosphere (Guenther et al., 1995). Once emitted, BVOCs oxidise to yield a range of lower volatility oxidation products that can partition into the aerosol phase, forming secondary organic aerosol (SOA) (Kavouras et al., 1998; O'Dowd et al., 2002; Kanakidou et al., 2005; Jimenez et al., 2009). The oxidation products of monoterpenes and isoprene have been observed in both ambient aerosol (e.g. Kavouras et al., 1999; Yu et al., 1999b; Claeys et al., 2004; Robinson et al., 2011) and in laboratory chamber experiments (e.g. Hatakeyama et al., 1989; Edney et al., 2005; Kroll et al., 2005, 2006). Over Scandinavia, parcels of air have 
been found to contain an aerosol mass that is proportional to the length of time the air has spent over forested land (Tunved et al., 2006, 2008), suggesting an important contribution to aerosol from BVOC emissions.

Whilst organic aerosol has been shown to dominate the mass of fine aerosol over much of the world (Zhang et al., 2007; Jimenez et al., 2009), the climate effects of biogenic SOA are not well understood. The presence of SOA can influence the Earth's radiative balance by contributing to the absorption and scattering of radiation (the direct effect) and by altering the properties of clouds (indirect effects) (Forster et al., 2007). Incoming solar radiation peaks at wavelengths between $380 \mathrm{~nm}$ and $750 \mathrm{~nm}$, so processes that aid in the growth of particles up to these sizes, such as the condensation of secondary organic material, will have a direct radiative effect (DRE). The annual global DRE from biogenic SOA has been previously estimated at between $-0.01 \mathrm{~W} \mathrm{~m}^{-2}$ (all sky; Goto et al., 2008) and $-0.29 \mathrm{~W} \mathrm{~m}^{-2}$ (clear sky; O'Donnell et al., 2011), but regional effects may be much larger, e.g. up to $-1 \mathrm{~W} \mathrm{~m}^{-2}$ over tropical forest regions (Rap et al., 2013) and a Northern Hemisphere (NH) summertime mean of between $-0.37 \mathrm{~W} \mathrm{~m}^{-2}$ and $-0.74 \mathrm{~W} \mathrm{~m}^{-2}$ over boreal regions (Lihavainen et al., 2009).

The first aerosol indirect effect (AIE), or cloud albedoeffect, describes the radiative perturbation resulting from a change to the number concentration of cloud droplets when a fixed cloud water content is assumed (Twomey, 1977). This change is governed by the number of particles in the atmosphere that are able to act as cloud condensation nuclei (CCN), as determined by their size and chemical composition (Penner et al., 2001; Dusek et al., 2006). SOA formed from the oxidation products of isoprene and monoterpenes has been shown to be $\mathrm{CCN}$-active under atmospherically relevant conditions, with a hygroscopicity parameter close to 0.1 (Duplissy et al., 2008; Engelhart et al., 2008, 2011).

The presence of SOA can affect CCN number concentrations in several ways. Organic compounds are known to aid in the growth of newly formed particles ( $\sim 1-2 \mathrm{~nm}$ diameter) to observable sizes (> $3 \mathrm{~nm}$ diameter; Boy et al., 2003; Kulmala et al., 2004; Verheggen et al., 2007; Laaksonen et al., 2008; Pierce et al., 2011; Yli-Juuti et al., 2011; Riccobono et al., 2012) and even further to a CCN-active size (> $\sim 70 \mathrm{~nm}$ diameter; Riipinen et al., 2011, 2012; Pierce et al., 2012; Paasonen et al., 2013). Additionally, the oxidation products of terpenes may play a role in the initial stages of particle formation via stabilisation of the critical nucleus (Fan et al., 2006; Zhang et al., 2009; Metzger et al., 2010; Paasonen et al., 2010; Kulmala et al., 2013). By contrast, both laboratory (Kiendler-Scharr et al., 2009) and field experiments (Kanawade et al., 2011) indicate that isoprene emissions may act to suppress new particle formation in the presence of high isoprene to monoterpene emission ratios, although the mechanism through which this process operates is not known.

Several studies suggest a large first AIE from biogenic SOA over the boreal forests at high northern latitudes.
Using a global aerosol microphysics model, Spracklen et al. (2008a) simulated a doubling of regional summertime $\mathrm{CCN}$ concentrations as a result of monoterpene emissions, and a subsequent regional first AIE of between -1.8 and $-6.7 \mathrm{~W} \mathrm{~m}^{-2}$ of boreal forest. Using measurements made at Pallas in Finland, Lihavainen et al. (2009) estimated a local summertime first AIE of between -3.2 and $-6.4 \mathrm{~W} \mathrm{~m}^{-2}$ over the boreal forest region. A stronger annual first AIE (locally between -5 and $-14 \mathrm{~W} \mathrm{~m}^{-2}$ ) was calculated by Kurten et al. (2003) using measurements taken at Hyytiälä in southern Finland. Globally, the AIE is weaker, and previous estimates range from negative to positive values. Rap et al. (2013) estimate a global annual mean first AIE of $-0.02 \mathrm{~W} \mathrm{~m}^{-2}$ due to monoterpene SOA, and Goto et al. (2008) simulate an AIE (including cloud lifetime and semi-direct effects) of $-0.19 \mathrm{~W} \mathrm{~m}^{-2}$. However, Goto et al. (2008) use an aerosol model that treats aerosol mass only, which is not ideal when examining processes that will influence the number size distribution (Bellouin et al., 2013). By contrast, O'Donnell et al. (2011) simulate a decrease in global mean CCN concentration and therefore a positive AIE of $+0.23 \mathrm{~W} \mathrm{~m}^{-2}$ for the emission of both biogenic and anthropogenic volatile organic compounds (VOCs), potentially due to their differing microphysical treatment of SOA.

The aim of this study is to quantify the radiative effects of biogenic SOA in the present-day atmosphere and examine the sensitivity to several important processes and parameters. We simulate changes in the global aerosol distribution resulting from the emission of BVOCs and calculate the DRE and first AIE. In order to examine the influence of present-day anthropogenic emissions on the radiative effect of biogenic SOA, we also calculate the radiative effect of SOA in a preindustrial atmosphere.

\section{Method}

\subsection{Model description}

The Global Model of Aerosol Processes (GLOMAP; Spracklen et al., 2005a) is an extension to the TOMCAT global 3-D chemical transport model (Chipperfield, 2006). Here we use GLOMAP-mode (version 6), in which information about aerosol component masses and number concentrations is carried in five log-normal size modes (Mann et al., 2010, 2012): four hydrophilic (nucleation, Aitken, accumulation and coarse), and a non-hydrophilic Aitken mode. Material in the particle phase is classified into four components: sulphate (SU), black carbon (BC), particulate organic matter (POM) and sea salt (SS). GLOMAP includes representations of nucleation, particle growth via coagulation, condensation and cloud processing, wet and dry deposition, and, in- and below-cloud scavenging.

The model has a horizontal resolution of $2.8^{\circ} \times 2.8^{\circ}$ with $31 \sigma$-pressure levels from the surface to $10 \mathrm{hPa}$. Meteorology 
Table 1. BVOC reaction rates used in this study (Atkinson et al., 1989, 2006).

\begin{tabular}{lr}
\hline Reaction & Rate coefficient $\left(\mathrm{cm}^{3} \mathrm{~s}^{-1}\right)$ \\
\hline$\alpha$-pinene $+\mathrm{OH}$ & $1.2 \times 10^{-11} \exp (444 / T)$ \\
$\alpha$-pinene $+\mathrm{O}_{3}$ & $1.01 \times 10^{-15} \exp (-732 / T)$ \\
$\alpha$-pinene $+\mathrm{NO}_{3}$ & $1.19 \times 10^{-12} \exp (490 / T)$ \\
isoprene $+\mathrm{OH}$ & $2.7 \times 10^{-11} \exp (390 / T)$ \\
isoprene $+\mathrm{O}_{3}$ & $1.0 \times 10^{-14} \exp (-1995 / T)$ \\
isoprene $+\mathrm{NO}_{3}$ & $3.15 \times 10^{-12} \exp (-450 / T)$ \\
\hline
\end{tabular}

is obtained from European Centre for Medium-Range Weather Forecasts (ECMWF) reanalyses at six -hourly intervals and cloud fields from the International Satellite Cloud Climatology Project (ISCCP) archive (Rossow and Schiffer, 1999). All simulations are performed for the year 2000, with six months' spin-up from zero initial aerosol.

\subsubsection{Gas-phase emissions and chemistry}

Monthly emissions of monoterpenes and isoprene are taken from the Global Emissions InitiAtive (GEIA) database (Guenther et al., 1995), which gives total emissions of 127 and $503 \operatorname{Tg}(\mathrm{C}) \mathrm{a}^{-1}$ respectively. Considerable variability is observed in the yield of SOA generated by BVOC oxidation (e.g. Yu et al., 1999a; Kroll et al., 2006; Shilling et al., 2009). Here we generate SOA at fixed molar yields of $13 \%$ and $3 \%$ for the oxidation of monoterpenes and isoprene respectively; monoterpenes are prescribed the reaction characteristics of $\alpha$-pinene and oxidation reactions proceed at the rates given in Table 1 . The use of a $13 \%$ molar yield for the production of monoterpene SOA follows the approach of Spracklen et al. (2006), which was based on Tunved et al. (2004a). Tunved et al. (2006) revised this estimate downwards to an apparent mass yield of between 5 and $10 \%$, suggesting that the atmospheric yield may be lower than the $13 \%$ molar yield (equivalent to a $14.3 \%$ mass yield) used in GLOMAP. The $3 \%$ molar yield (equivalent to a $3.3 \%$ mass yield) for the production of isoprene SOA is based on the yields obtained by Kroll et al. $(2005,2006)$ over a range of experimental conditions (0.9-5.5\% mass yield).

The global production of biogenic SOA is poorly constrained, with estimates ranging between $12 \mathrm{Tg}(\mathrm{SOA}) \mathrm{a}^{-1}$ and $1820 \mathrm{Tg}(\mathrm{SOA}) \mathrm{a}^{-1}$ (Griffin et al., 1999; Kanakidou et al., 2005; Goldstein and Galbally, 2007; Heald et al., 2010, 2011; Spracklen et al., 2011b). Using molar yields of $13 \%$ and $3 \%$ (for monoterpenes and isoprene respectively) produces approximately $37 \mathrm{Tg}(\mathrm{SOA}) \mathrm{a}^{-1}$ in our model, which is towards the lower end of current estimates. Consequently, it may be the case that the yields applied here are too low (i.e. do not produce enough SOA), or too high (Tunved et al., 2006). We explore this uncertainty by varying the SOA production yield in a series of sensitivity experiments.
Global aerosol modelling studies commonly assume that the organic material generated by BVOC oxidation is either non-volatile (Spracklen et al., 2008a; Pierce and Adams, 2009; Makkonen et al., 2012) or semi-volatile (Pye and Seinfeld, 2010; O'Donnell et al., 2011). When semi-volatile products are partitioned with an equilibrium approach, organics are preferentially added to larger size particles, with negligible particle mass added to smaller particles. However, organic oxidation products are observed in nucleation mode particles (Smith et al., 2008) and measurement-modelling studies suggest that their volatility is low (Pierce et al., 2011). Furthermore, newly formed particles do not grow to their measured sizes if organic oxidation products are assumed not to partition to growing nuclei (Riipinen et al., 2011). In this work, in order to account for the growth of new particles, we assume that BVOCs oxidise to form non-volatile organic material which condenses irreversibly onto existing aerosol according to their Fuchs-Sutugin-corrected surface area (Fuchs and Sutugin, 1971). Sensitivity to the approach used for gas to particle partitioning is examined in another publication (Scott et al., 2014).

We prescribe six-hourly mean offline oxidant $\left(\mathrm{OH}, \mathrm{O}_{3}\right.$, $\mathrm{NO}_{3}, \mathrm{HO}_{2}, \mathrm{H}_{2} \mathrm{O}_{2}$ ) concentrations from a previous TOMCAT simulation (Arnold et al., 2005). GLOMAP also includes phytoplankton emissions of dimethyl-sulphide (DMS), calculated using monthly sea-water DMS concentrations from Kettle and Andreae (2000), and gas-phase sulphur dioxide $\left(\mathrm{SO}_{2}\right)$ emissions from anthropogenic sources (Cofala et al., 2005), wildfires (van der Werf et al., 2004), and both continuous (Andres and Kasgnoc, 1998) and explosive (Halmer et al., 2002) volcanic eruptions.

\subsubsection{Primary particulate emissions}

Annual mean emissions of BC and POM from fossil and biofuel combustion are based on energy data from 1996 and taken from Bond et al. (2004); monthly wildfire emissions for the year 2000 are from the Global Fire Emissions Database (GFED) inventory (van der Werf et al., 2004). In a sensitivity study we use wildfire and anthropogenic emissions from the year 1750, compiled for the AeroCom initiative (Dentener et al., 2006). The emission of primary sea-salt aerosol is parameterised according to Gong (2003).

\subsubsection{New particle formation}

Since new particle formation has been shown to strongly affect CCN concentrations (Spracklen et al., 2008b) and simulated aerosol indirect radiative effects (Bellouin et al., 2013), we quantify the impact of BVOC emissions using four nucleation mechanisms. In all experiments we include a parameterisation to represent the binary homogeneous nucleation (BHN) of sulphuric acid and water (Kulmala et al., 1998a) which occurs mainly in the free troposphere (e.g. Spracklen et al., 2005b). New particle formation rates in the boundary 
layer cannot be adequately explained by BHN alone, so we examine the impact of BVOC emissions when three additional parameterisations for new particle formation are applied in the boundary layer, in combination with BHN. The first parameterisation is an empirically derived mechanism for the activation (ACT) of sulphuric acid clusters in the boundary layer based on the work of Kulmala et al. (2006). With this approach, molecular clusters activate at a rate $\left(J_{\text {Act }}^{*}\right)$ proportional to the gas-phase concentration of sulphuric acid (Eq. 1). The coefficient $A$ represents the complexity of the activation process and may be a function of several parameters such as temperature and the concentration of other species (potentially organics). Here we use a value for $A$ of $2 \times 10^{-6} \mathrm{~s}^{-1}$ (as determined empirically by Sihto et al., 2006) and restrict this mechanism to the boundary layer, allowing BHN to proceed at higher altitudes.

$J_{\text {Act }}^{*}=A\left[\mathrm{H}_{2} \mathrm{SO}_{4}\right]$

The final two parameterisations, Org1 (Eq. 2) and Org2 (Eq. 3) are implemented using the particle formation rates described by Metzger et al. (2010) and Paasonen et al. (2010) respectively $\left(k=5 \times 10^{-13} \mathrm{~s}^{-1}\right.$, $\left.k_{1}=1.1 \times 10^{-14} \mathrm{~s}^{-1}, k_{2}=3.2 \times 10^{-14} \mathrm{~s}^{-1}\right)$. In smog chamber experiments, Metzger et al. (2010) found that particle formation rates were proportional to the product of the gas-phase concentrations of sulphuric acid and low volatility products from the photo-oxidation of an SOA precursor species (1,3,5-trimethylbenzene). They also found that sub$3 \mathrm{~nm}$ particle growth rates were too high to be explained by sulphuric acid vapour alone, and proposed that organic oxidation products were also required to explain the observations. Paasonen et al. (2010) found a good correlation against a wide observational data set when the particle formation rate combined a term based on the product of the concentrations of sulphuric acid and an organic molecule with a kinetic nucleation term proportional to the square of sulphuric acid concentration. When implementing these two organically mediated nucleation mechanisms, we include only the product from monoterpene oxidation as the organic oxidation product, since the role of isoprene oxidation products in new particle formation remains unclear. Our experiments therefore apply these two nucleation rate parameterisations (Eqs. 2 and 3) throughout the atmosphere, using the first stage product from monoterpene oxidation as the condensable organic species, "org":

$J_{\text {Org } 1}^{*}=k\left[\mathrm{H}_{2} \mathrm{SO}_{4}\right][\mathrm{org}]$,

$J_{\mathrm{Org} 2}^{*}=k_{1}\left[\mathrm{H}_{2} \mathrm{SO}_{4}\right]^{2}+k_{2}\left[\mathrm{H}_{2} \mathrm{SO}_{4}\right][\mathrm{org}]$.

As the focus of this study is to investigate the role of biogenic SOA, we do not consider ternary homogeneous nucleation, but, as has been shown recently by Almeida et al. (2013), ternary nucleation involving amines may be an important process in the boundary layer.
The growth of newly formed clusters is not simulated explicitly, but the production rate $J_{m}$ of particles at a measurable size (taken as $d_{m}=3 \mathrm{~nm}$ ) is calculated using the approximation of Kerminen and Kulmala (2002), as given in Eq. (4). The dry cluster diameter, $d^{*}$, is taken as $0.8 \mathrm{~nm}$ for $J_{\text {Act }}^{*}, 1.5 \mathrm{~nm}$ for $J_{\text {Org1 }}^{*}$ (Metzger et al., 2010), and $2 \mathrm{~nm}$ for $J_{\text {Org2 }}^{*}$ (Paasonen et al., 2010).

$J_{m}=J^{*} \exp \left[0.23\left(\frac{1}{d_{m}}-\frac{1}{d^{*}}\right) \frac{\mathrm{CS}^{\prime}}{\mathrm{GR}}\right]$

This production rate accounts for scavenging by larger particles, and allows growth of nucleated clusters up to $d_{m}$ at a constant growth rate, GR, proportional to the gas-phase concentration of sulphuric acid. The reduced condensation sink, $\mathrm{CS}^{\prime}$, is calculated by integrating over the aerosol size modes following Kulmala et al. (2001b).

\subsection{Model experiments}

To examine the extent to which the simulated climate impacts of biogenic SOA are sensitive to our model's treatment of aerosol processes, we completed the series of model experiments described in Table 2. These simulations explore the impact of uncertainty in the SOA yield from BVOC oxidation, the role of organic oxidation products in new particle formation, and the interaction between SOA and primary carbonaceous aerosol emissions. To account for the uncertain yield of SOA produced by the oxidation of BVOCs, we varied the SOA mass yields by different factors (experiments 5 to 7 ), resulting in a global annual production of between $18.5 \mathrm{Tg}(\mathrm{SOA}) \mathrm{a}^{-1}$ and $185 \mathrm{Tg}(\mathrm{SOA}) \mathrm{a}^{-1}$. The global annual production of SOA from these yield experiments is detailed in Table 2 and all lie within the wide range of previous estimates (Griffin et al., 1999; Kanakidou et al., 2005; Goldstein and Galbally, 2007; Heald et al., 2010, 2011; Spracklen et al., 2011b).

In GLOMAP, the simulated aerosol size distributions, and therefore the $\mathrm{CCN}$ concentrations, are sensitive to the treatment of primary anthropogenic emissions (Reddington et al., 2011; Spracklen et al., 2011a), in particular the emission characteristics of primary carbonaceous aerosol. Here, we emit primary carbonaceous particles with the distribution characteristics described by Stier et al. (2005) in our standard simulations, i.e. number median diameter $D_{\mathrm{ff}}=60 \mathrm{~nm}$ and $D_{\mathrm{bf}}=150 \mathrm{~nm}$, standard deviation $\sigma_{\mathrm{ff}}=1.59$ and $\sigma_{\mathrm{bf}}=1.59$ (where ff refers to fossil fuel and bf to biofuel/wildfire). We explore the sensitivity to this choice with an additional set of simulations (experiments 11 and 12) using smaller emission sizes $\left(D_{\mathrm{ff}}=30 \mathrm{~nm}, D_{\mathrm{bf}}=80 \mathrm{~nm}\right)$, but wider distributions $\left(\sigma_{\mathrm{ff}}=1.8, \sigma_{\mathrm{bf}}=1.8\right)$ recommended by AeroCom (Dentener et al., 2006).

The process of physical ageing, by which non-hydrophilic particles become hydrophilic via condensation of soluble material, is poorly understood (Kanakidou et al., 2005). In GLOMAP, primary BC/POM particles are emitted into a 
Table 2. Summary of model simulations and global annual mean changes to $\mathrm{N}_{3}$ (number concentration of particles $>3 \mathrm{~nm}$ diameter) at the surface, surface level CCN (0.2\% supersaturation) concentration, and CDNC at cloud height (approximately $900 \mathrm{hPa})$, with subsequent all-sky DRE and first AIE (highlighted in bold text), relative to an equivalent control simulation including no BVOC emission $($ Mon $=$ monoterpenes, Iso $=$ isoprene).

\begin{tabular}{|c|c|c|c|c|c|c|c|}
\hline Expt. no. & Description & $\begin{array}{l}\text { BVOC included } \\
\text { (Global production of } \\
\text { SOA given in brackets } \\
\left.\left(\mathrm{Tg}(\mathrm{SOA}) \mathrm{a}^{-1}\right)\right)\end{array}$ & $\begin{array}{l}\Delta \mathrm{N}_{3} \\
\left(\mathrm{~cm}^{-3}\right)\end{array}$ & $\begin{array}{l}\Delta \mathrm{CCN} \\
\left(\mathrm{cm}^{-3}\right)\end{array}$ & $\begin{array}{l}\triangle \mathrm{CDNC} \\
\left(\mathrm{cm}^{-3}\right)\end{array}$ & $\begin{array}{l}\text { All-sky DRE } \\
\left(\mathrm{Wm}^{-2}\right)\end{array}$ & $\begin{array}{l}\text { First AIE } \\
\left(\mathrm{W} \mathrm{m}^{-2}\right)\end{array}$ \\
\hline 1 & ACT & None & - & - & - & - & - \\
\hline 2 & $\begin{array}{l}\text { BHN with Eq. (1) within the } \\
\text { boundary layer }\end{array}$ & $\begin{array}{l}\text { Mon } \\
(20.4)\end{array}$ & $\begin{array}{l}-64.3 \\
(-7.9 \%)\end{array}$ & $\begin{array}{l}+23.5 \\
(+10.4 \%)\end{array}$ & $\begin{array}{l}+7.7 \\
(+4.1 \%)\end{array}$ & -0.10 & -0.07 \\
\hline 3 & & $\begin{array}{l}\text { Iso } \\
\text { (16.6) }\end{array}$ & $\begin{array}{l}-43.1 \\
(-5.3 \%)\end{array}$ & $\begin{array}{l}+19.3 \\
(+8.5 \%)\end{array}$ & $\begin{array}{l}+5.9 \\
(+3.2 \%)\end{array}$ & -0.08 & -0.06 \\
\hline 4 & & $\begin{array}{l}\text { Mon + Iso } \\
(37.0)\end{array}$ & $\begin{array}{l}-79.6 \\
(-9.7 \%)\end{array}$ & $\begin{array}{l}+29.0 \\
(+12.8 \%)\end{array}$ & $\begin{array}{l}+8.2 \\
(+4.4 \%)\end{array}$ & -0.18 & -0.06 \\
\hline 5 & $\begin{array}{l}\text { ACT_x0.5 } \\
0.5 \times \text { SOA production yield* }\end{array}$ & $\begin{array}{l}\text { Mon + Iso } \\
(18.5)\end{array}$ & $\begin{array}{l}-56.7 \\
(-6.9 \%)\end{array}$ & $\begin{array}{l}+22.1 \\
(+9.7 \%)\end{array}$ & $\begin{array}{l}+7.1 \\
(+3.8 \%)\end{array}$ & -0.09 & -0.07 \\
\hline 6 & $\begin{array}{l}\text { ACT_x2 } \\
2 \times \text { SOA production yield* }\end{array}$ & $\begin{array}{l}\text { Mon + Iso } \\
(74.0)\end{array}$ & $\begin{array}{l}-106.7 \\
(-13.0 \%)\end{array}$ & $\begin{array}{l}+36.7 \\
(+16.2 \%)\end{array}$ & $\begin{array}{l}+9.0 \\
(+4.8 \%)\end{array}$ & -0.33 & -0.04 \\
\hline 7 & $\begin{array}{l}\text { ACT_x5 } \\
5 \times \text { SOA production yield* }\end{array}$ & $\begin{array}{l}\text { Mon + Iso } \\
(185.1)\end{array}$ & $\begin{array}{l}-145.5 \\
(-17.8 \%)\end{array}$ & $\begin{array}{l}+48.0 \\
(+21.1 \%)\end{array}$ & $\begin{array}{l}+9.3 \\
(+5.0 \%)\end{array}$ & -0.78 & +0.01 \\
\hline 8 & $\begin{array}{l}\text { ACT_noSOAage } \\
\text { No transfer of non-hydrophilic par- } \\
\text { ticles to the hydrophilic distribution } \\
\text { via condensation of secondary or- } \\
\text { ganics }\end{array}$ & $\begin{array}{l}\text { Mon + Iso } \\
(37.0)\end{array}$ & $\begin{array}{l}-81.3 \\
(-9.9 \%)\end{array}$ & $\begin{array}{l}+8.3 \\
(+3.6 \%)\end{array}$ & $\begin{array}{l}+3.6 \\
(+1.9 \%)\end{array}$ & -0.14 & -0.02 \\
\hline $\begin{array}{l}9 \\
10\end{array}$ & $\begin{array}{l}\text { ACT_fast_age } \\
\text { One soluble monolayer required to } \\
\text { transfer non-hydrophilic particles } \\
\text { to the hydrophilic distribution }\end{array}$ & $\begin{array}{l}\text { None } \\
\text { Mon + Iso } \\
(37.0)\end{array}$ & $\begin{array}{l}- \\
-81.5 \\
(-9.9 \%)\end{array}$ & $\begin{array}{l}- \\
+21.8 \\
(+8.9 \%)\end{array}$ & $\begin{array}{l}- \\
+4.9 \\
(+2.5 \%)\end{array}$ & $\begin{array}{l}- \\
-0.18\end{array}$ & $\begin{array}{l}- \\
-0.02\end{array}$ \\
\hline $\begin{array}{l}11 \\
12\end{array}$ & $\begin{array}{l}\text { ACT_PriCarb_small } \\
\text { Size distribution of primary car- } \\
\text { bonaceous emissions set to Aero- } \\
\text { Com recommendation (Dentener et } \\
\text { al., 2006). }\end{array}$ & $\begin{array}{l}\text { None } \\
\text { Mon + Iso } \\
(37.0)\end{array}$ & $\begin{array}{l}- \\
-55.8 \\
(-5.0 \%)\end{array}$ & $\begin{array}{l}- \\
+46.0 \\
(+17.5 \%)\end{array}$ & $\begin{array}{l}- \\
+10.4 \\
(+5.2 \%)\end{array}$ & $\begin{array}{l}- \\
-0.18\end{array}$ & $\begin{array}{l}- \\
-0.12\end{array}$ \\
\hline $\begin{array}{l}13 \\
14\end{array}$ & $\begin{array}{l}\text { BHN } \\
\text { Binary homogeneous nucleation } \\
\text { only }\end{array}$ & $\begin{array}{l}\text { None } \\
\text { Mon } \\
(20.4)\end{array}$ & $\begin{array}{l}- \\
-1.7 \\
(-0.4 \%)\end{array}$ & $\begin{array}{l}- \\
+20.3 \\
(+10.4 \%)\end{array}$ & $\begin{array}{l}- \\
+5.8 \\
(+3.5 \%)\end{array}$ & $\begin{array}{l}- \\
-0.10\end{array}$ & $\begin{array}{l}- \\
-0.05\end{array}$ \\
\hline $\begin{array}{l}15 \\
16\end{array}$ & $\begin{array}{l}\text { Org1 } \\
\text { BHN with Eq. (2) throughout the } \\
\text { atmosphere }\end{array}$ & $\begin{array}{l}\text { None } \\
\text { Mon } \\
(20.4)\end{array}$ & $\begin{array}{l}- \\
+643.0 \\
(+142 \%)\end{array}$ & $\begin{array}{l}- \\
+88.1 \\
(+45.2 \%)\end{array}$ & $\begin{array}{l}- \\
+44.2 \\
(+26.6 \%)\end{array}$ & $\begin{array}{l}- \\
-0.08\end{array}$ & $\begin{array}{l}- \\
-0.77\end{array}$ \\
\hline $\begin{array}{l}17 \\
18\end{array}$ & $\begin{array}{l}\text { Org2 } \\
\text { BHN with Eq. (3) throughout the } \\
\text { atmosphere }\end{array}$ & $\begin{array}{l}\text { None } \\
\text { Mon } \\
(20.4)\end{array}$ & $\begin{array}{l}- \\
+188.0 \\
(+22.0 \%)\end{array}$ & $\begin{array}{l}- \\
+39.0 \\
(+15.5 \%)\end{array}$ & $\begin{array}{l}- \\
+14.3 \\
(+7.2 \%)\end{array}$ & 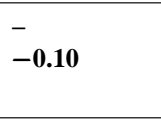 & $\begin{array}{l}- \\
-0.22\end{array}$ \\
\hline $\begin{array}{l}19 \\
20\end{array}$ & $\begin{array}{l}\text { ACT_1750 } \\
1750 \text { emissions of } \mathrm{BC} \text { (wildfire, } \\
\text { biofuel), POM (wildfire, biofuel) } \\
\text { and } \mathrm{SO}_{2} \text { (wildfire, domestic) taken } \\
\text { from Dentener et al. (2006). }\end{array}$ & $\begin{array}{l}\text { None } \\
\text { Mon + Iso } \\
(37.0)\end{array}$ & $\begin{array}{l}- \\
-127.3 \\
(-21.1 \%)\end{array}$ & $\begin{array}{l}- \\
+23.8 \\
(+23.2 \%)\end{array}$ & $\begin{array}{l}- \\
+12.8 \\
(+12.6 \%)\end{array}$ & $\begin{array}{l}- \\
-0.18\end{array}$ & $\begin{array}{l}- \\
-0.19\end{array}$ \\
\hline $\begin{array}{l}21 \\
22\end{array}$ & $\begin{array}{l}\text { Org1_1750 } \\
1750 \text { emissions of BC (wildfire, } \\
\text { biofuel), POM (wildfire, biofuel) } \\
\text { and } \mathrm{SO}_{2} \text { (wildfire, domestic) taken } \\
\text { from Dentener et al. (2006). }\end{array}$ & $\begin{array}{l}\text { None } \\
\text { Mon } \\
(20.4)\end{array}$ & $\begin{array}{l}- \\
+437.3 \\
(+171 \%)\end{array}$ & $\begin{array}{l}- \\
+52.5 \\
(+56.7 \%)\end{array}$ & $\begin{array}{l}- \\
+34.9 \\
(+37.9 \%)\end{array}$ & $\begin{array}{l}- \\
-0.12\end{array}$ & $\begin{array}{l}- \\
-0.95\end{array}$ \\
\hline
\end{tabular}

* Experiments 5-7 were repeated with 1750 emissions of $\mathrm{BC}$, POMand $\mathrm{SO}_{2}$ to examine the effect of altering the yield of SOA production in a pre-industrial atmosphere. 
non-hydrophilic distribution and transferred to an internally mixed hydrophilic distribution after the condensation of a specific amount of condensable material. Our standard simulations assume that ten monolayers of condensable material (secondary organics or sulphuric acid) are required to coat an insoluble particle sufficiently for it to become soluble. To examine the importance of this process and its representation with respect to the impact of biogenic SOA, we perform one simulation in which physical ageing does not occur as a result of the condensation of secondary organics (experiment 8 ), and others in which only one soluble monolayer is required (experiments 9 and 10).

The sensitivities examined here are not intended to provide an exhaustive assessment of the uncertainty associated with the radiative impact of biogenic SOA, but to highlight the importance of several key parameters in determining the direct and indirect effects. A more thorough assessment of sensitivities and feedbacks would require an emulator-style approach (e.g. Lee et al., 2012) to model the entire parameter space.

\subsection{Calculation of $\mathrm{CCN}$ concentrations}

$\mathrm{CCN}$ concentrations were calculated offline, from monthly mean aerosol tracers, using the approach of Petters and Kreidenweis (2007). A hygroscopicity parameter $(\kappa)$ is assigned to each component; a multi-component $\kappa_{\text {multi }}$ is then obtained by weighting the individual $\kappa$ values by the volume fraction of each component. We assign the following individual hygroscopicity parameters: sulphate $(0.61$, assuming ammonium sulphate), sea salt (1.28), black carbon (0.0), and particulate organic matter $(0.1)$. Whilst there is uncertainty associated with the hygroscopicity parameter for organic material in the atmosphere due to the wide range of solubilities observed, $\kappa$ values close to 0.1 have been reported for secondary organic components (Engelhart et al., 2008, 2011; Gunthe et al., 2009; Dusek et al., 2010; King et al., 2010), and the entire organic fraction (Wang et al., 2008; Chang et al., 2010). We calculate $\mathrm{CCN}$ concentrations at a supersaturation of $0.2 \%$, which is equivalent to an activation dry diameter of approximately $80 \mathrm{~nm}$ (assuming a composition of pure ammonium sulphate). We assume that $\mathrm{BC} / \mathrm{POM}$ particles in the non-hydrophilic distribution do not act as CCN.

\subsection{Cloud droplet number concentration}

Cloud droplet number concentrations (CDNC) are calculated using the parameterisation of Nenes and Seinfeld (2003), as updated by Fountoukis and Nenes (2005) and Barahona et al. (2010). The monthly mean aerosol size distribution is converted to a supersaturation distribution from which the number of activated particles can be determined for the diagnosed maximum supersaturation $\left(S_{\max }\right)$. The $S_{\max }$ of an ascending cloud parcel represents the competition between increasing water vapour saturation with decreasing tempera- ture, and the loss of water vapour through condensation onto activated particles. As such, $S_{\max }$ depends upon the aerosol population and should be diagnosed rather than prescribed uniformly, as discussed by Pringle et al. (2009). Here, CDNC are calculated with a prescribed constant updraught velocity of $0.15 \mathrm{~m} \mathrm{~s}^{-1}$ over sea and $0.3 \mathrm{~m} \mathrm{~s}^{-1}$ over land, consistent with those commonly observed for low-level stratus and stratocumulus clouds (Guibert et al., 2003; Peng et al., 2005; Pringle et al., 2012).

\subsection{Radiative effects}

The DRE and first AIE of biogenic SOA are determined using the offline radiative transfer model of Edwards and Slingo (1996) with nine bands in the longwave and six bands in the shortwave. We use a monthly mean climatology based on ECMWF reanalysis data, together with cloud fields from the ISCCP-D2 archive (Rossow and Schiffer, 1999) for the year 2000. Sensitivity of direct and first indirect radiative effects to the cloud climatology used (i.e. single year versus multi-annual mean) was examined in Rap et al. (2013) and found be to be negligible for a range of natural aerosol sources, including monoterpene-derived SOA.

To determine the DRE, following the methodology described in Rap et al. (2013), the radiative transfer model is used to calculate the difference in net top-of-atmosphere (SW + LW) all-sky radiative flux between experiments including SOA and the equivalent experiments without SOA. Aerosol scattering and absorption coefficients together with asymmetry parameters are calculated for each aerosol size mode and spectral band, as described in Bellouin et al. (2013).

The first AIE is calculated as in Schmidt et al. (2012); a uniform control cloud droplet effective radius $\left(r_{\mathrm{e} 1}\right)$ of $10 \mu \mathrm{m}$ is assumed to maintain consistency with the ISCCP cloud data, and for each perturbation experiment the effective radius $\left(r_{\mathrm{e} 2}\right)$ is calculated as in Eq. (5), from cloud droplet number fields $\mathrm{CDNC}_{1}$ and $\mathrm{CDNC}_{2}$ respectively. For each experiment, $\mathrm{CDNC}_{1}$ represents the simulation including SOA, and $\mathrm{CDNC}_{2}$ represents the simulation with no SOA.

$r_{\mathrm{e} 2}=r_{\mathrm{e} 1} \times\left[\frac{\mathrm{CDNC}_{1}}{\mathrm{CDNC}_{2}}\right]^{\frac{1}{3}}$

The first AIE of biogenic SOA is then calculated by comparing net $(\mathrm{SW}+\mathrm{LW})$ radiative fluxes (using the varying $r_{\mathrm{e} 2}$ values derived for each perturbation experiment), to those of the control simulation with fixed $r_{\mathrm{e} 1}$. In these offline experiments, we do not calculate the second aerosol indirect (cloud lifetime) effect. 

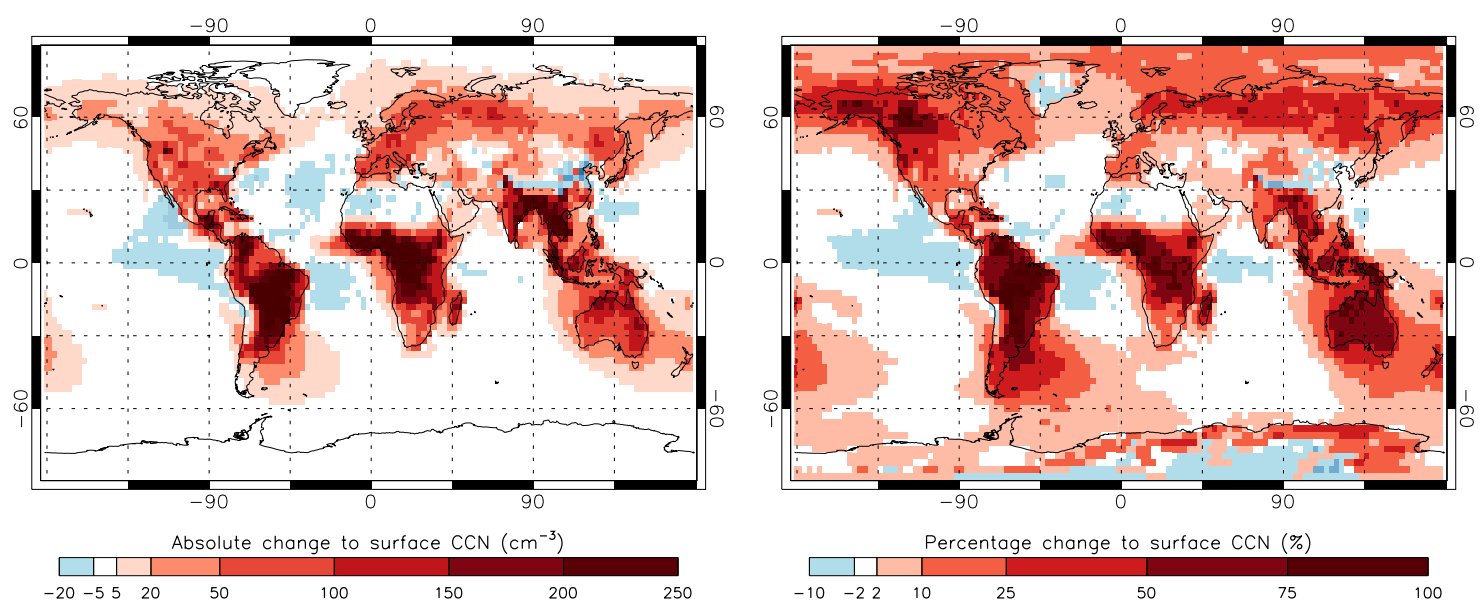

Fig. 1. Simulated annual mean absolute (left) and percentage (right) change to surface cloud condensation nuclei (CCN) number concentration, calculated at $0.2 \%$ supersaturation, resulting from the emission of both monoterpenes and isoprene when the ACT mechanism is used.

\section{Results}

\subsection{Changes to total particle and $\mathrm{CCN}$ number concentrations}

Table 2 reports the impact of biogenic SOA on simulated aerosol properties. SOA increases the condensation sink, potentially suppressing new particle formation and growth. This results in the global annual mean total particle $\left(\mathrm{N}_{3}\right.$; greater than $3 \mathrm{~nm}$ dry diameter) concentration being reduced by $7.9 \%$ when monoterpene emissions are included with activation boundary layer nucleation (experiment 2 ) and by $0.4 \%$ when BHN is the only new particle formation mechanism (experiment 14). By contrast, when organics contribute directly to nucleation (experiments 16 and 18), a global annual mean increase in $\mathrm{N}_{3}$ of between $22.0 \%$ and $142.0 \%$ is simulated. In these simulations, the additional nucleation caused by the presence of organics dominates the moderate reduction in $\mathrm{N}_{3}$ due to the enhanced condensation sink.

In all the model configurations examined here, biogenic SOA increases the simulated global annual mean surface $\mathrm{CCN}$ concentration, with the relative enhancement ranging between $3.6 \%$ and $45.2 \%$ (Table 2). The spatial distribution of changes to $\mathrm{CCN}$ concentration (Fig. 1) does not simply match the distribution of BVOC emissions due to the diverse range of processes controlling the aerosol size distribution and CCN number. For the ACT simulation shown in Fig. 1, biogenic SOA (from monoterpenes and isoprene) increases annual mean CCN concentrations by up to $120 \%$ over the Amazon, whilst reducing annual mean $\mathrm{CCN}$ concentrations by up to $8 \%$ over some tropical oceans.

The largest increases in absolute $\mathrm{CCN}$ concentration are simulated in regions experiencing high levels of primary particulate emissions, particularly tropical regions affected by biomass burning. This suggests an important relationship be- tween SOA and the presence of primary particles. In our model, primary carbonaceous aerosol from fossil fuel combustion and wildfire is initially non-hydrophilic, being emitted into the Aitken insoluble mode. Condensation of soluble gas-phase species moves these particles into the hydrophilic Aitken mode, where they are able to act as CCN. Without this physical ageing by SOA, the global annual mean increase in $\mathrm{CCN}$ concentration is reduced to $3.6 \%$ (experiment 8 ), compared to $12.8 \%$ in the equivalent standard run (experiment 4 ). When the physical ageing requires only one monolayer of soluble material (experiment 10), the global mean increase in $\mathrm{CCN}$ number concentration is reduced to $8.9 \%$ because carbonaceous particles are more efficiently coated and transferred to the hydrophilic distribution by sulphuric acid, such that $\mathrm{CCN}$ concentrations are less sensitive to the presence of organics. Using a smaller emission size for primary carbonaceous aerosol (experiment 12) increases the global annual mean change to surface $\mathrm{CCN}$ concentrations when biogenic SOA is included to $17.5 \%$. A smaller emission size increases the number of primary particles emitted per mass of carbonaceous material, thereby providing more non-hydrophilic particles ready to be aged to the hydrophilic modes where they are able to act as CCN. Additionally, the lower surface area of smaller particles allows a faster rate of ageing by a given amount of SOA.

At tropical latitudes $\left(30^{\circ} \mathrm{N}\right.$ to $\left.30^{\circ} \mathrm{S}\right)$, high year-round emissions of both isoprene ( $87 \%$ of global total emissions) and monoterpenes ( $78 \%$ of total) result in large increases to $\mathrm{CCN}$ concentrations (Fig. 1) throughout the seasonal cycle (Fig. 2, left). At $30^{\circ} \mathrm{N}$ to $90^{\circ} \mathrm{N}$, increases in $\mathrm{CCN}$ are largest during the summer, with small increases simulated in winter months when emissions of BVOC are low. Over the highlatitude boreal forests, monoterpene emissions are responsible for the majority of the CCN increase (Fig. 2, left), owing to their higher emission rate compared to isoprene. In the 

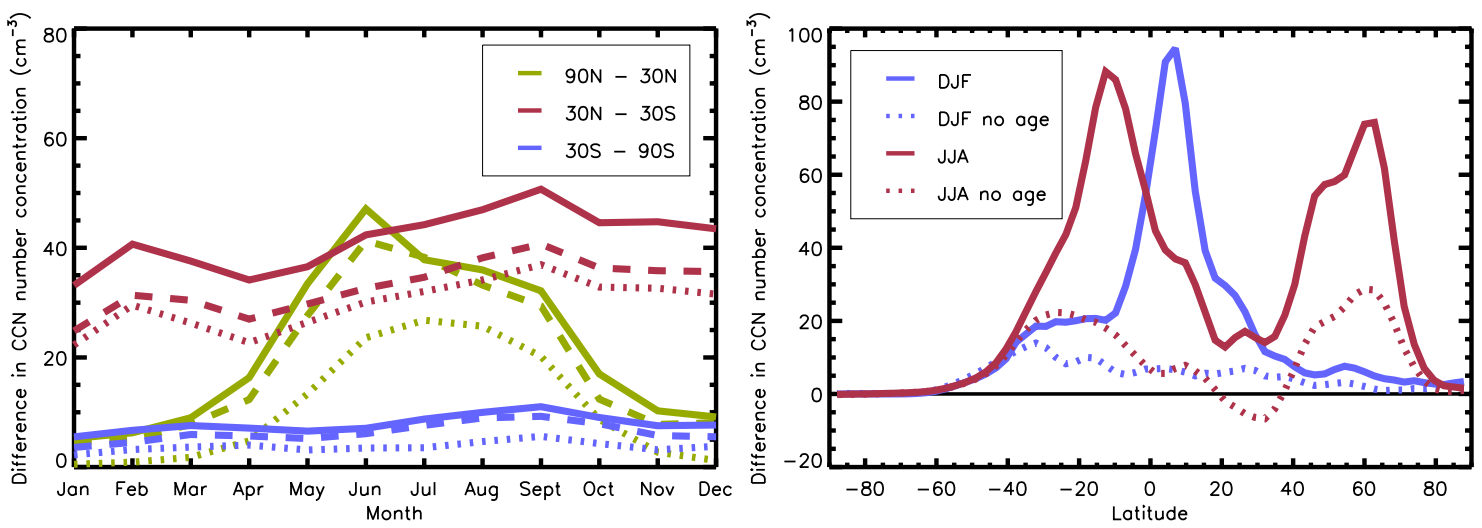

Fig. 2. Left: monthly mean absolute change in surface $\mathrm{CCN}$ number concentration $\left(\mathrm{cm}^{-3}\right)$ at $0.2 \%$ supersaturation, across three latitude bands, when monoterpene (expt. 2; dashed lines), isoprene (expt. 3; dotted lines) and both monoterpene and isoprene (expt. 4; solid lines) emissions are included in a simulation using the ACT mechanism. Right: seasonal mean absolute change in CCN number concentration $\left(\mathrm{cm}^{-3}\right)$ at $0.2 \%$ supersaturation during December-February (blue) and June-August (red) using the ACT mechanism; expt. 4 results (solid lines) include emissions of both monoterpenes and isoprene, expt. 8 results (dotted lines) are equivalent but condensable organics do not transfer hydrophobic particles to the hydrophilic distribution.

Southern Hemisphere ( $\mathrm{SH}$; specifically $30-90^{\circ} \mathrm{S}$ ), absolute $\mathrm{CCN}$ changes are small throughout the year due to low emissions of BVOC at these latitudes (Fig. 1, left and Fig. 2, left). However, relatively low absolute changes result in substantial fractional changes, particularly over the oceans (Fig. 1, right) due to low background $\mathrm{CCN}$ number concentration.

Within $30^{\circ}$ either side of the Equator, BVOC emissions from the GEIA inventory (Guenther et al., 1995) are slightly higher during the respective wet seasons (April-September in northern tropics; October-March in southern tropics), but as shown in Fig. 2 (right), the largest absolute increase in $\mathrm{CCN}$ concentration occurs during the dry seasons when primary carbonaceous emissions from wildfires are highest. The importance of ageing is confirmed by much lower CCN increase simulated when secondary organic material does not transfer hydrophobic particles to the hydrophilic distribution (dotted lines in Fig. 2, right). At high northern latitudes, the process of ageing also contributes to the summertime $\mathrm{CCN}$ increase (Fig. 2, right), but a more substantial contribution here comes from the growth of smaller particles to $\mathrm{CCN}$ active sizes via condensation of organic material.

BVOC emissions result in reductions in simulated $\mathrm{CCN}$ concentrations over some regions (Fig. 1). Reductions in $\mathrm{CCN}$ are driven by several different processes. Firstly, the presence of biogenic SOA enhances the condensation sink over continental regions, resulting in increased condensation of sulphuric acid to existing particles. This can lower sulphuric acid concentrations in the upper troposphere, subsequently reducing binary homogeneous nucleation and the number of particles entrained into the boundary layer. This entrainment of particles formed in the upper troposphere makes the largest contribution to surface $\mathrm{CCN}$ concentrations over the subtropical oceans (Merikanto et al., 2009). Additionally, in regions with particularly high $\mathrm{SO}_{2}$ emission (e.g. eastern Asia; Fig. 1), and therefore high $\mathrm{H}_{2} \mathrm{SO}_{4}$ concentrations, the enhanced condensation sink may also suppress new particle formation and growth as a route for $\mathrm{CCN}$ generation in the boundary layer, reducing $\mathrm{CCN}$ concentrations in the presence of biogenic SOA.

Secondly, the presence of biogenic SOA allows nonhydrophilic particles to be aged (i.e. transferred to the hydrophilic distribution) and enhances their growth up to the size at which they may be nucleation scavenged (taken here as particles with dry diameter $>206 \mathrm{~nm}$ ). In the absence of SOA, particle growth may only proceed via coagulation and condensation of sulphuric acid. Therefore in the presence of SOA, particles grow more quickly to a size where they may be removed from the atmosphere by wet deposition.

Monoterpene emissions contribute a greater increase to global annual mean $\mathrm{CCN}$ concentration than isoprene emissions (experiments 2 and 3; Table 2). This occurs partly because a greater amount of SOA is generated from their oxidation, despite total annual monoterpene emissions in the Guenther et al. (1995) data set being a factor of four lower than those for isoprene, but may also be due to the spatial distribution of emissions and relative proximity to sources of fine particles that require growth to reach $\mathrm{CCN}$ sizes (e.g. carbonaceous particles from fossil fuel combustion). As indicated in Fig. 2 (left), the contributions of each BVOC are not additive: monoterpene and isoprene SOA increase $\mathrm{CCN}$ concentrations by approximately $10.4 \%$ and $8.5 \%$ respectively, whereas the combined emission results in only $12.8 \%$ increase, suggesting a saturation of the global $\mathrm{CCN}$ response. This is confirmed by the variation in CCN change observed for experiments 4 to 7 , where a factor of 5 increase in the SOA production yield results in less than a doubling of absolute and fractional CCN changes. This occurs because the generation of additional $\mathrm{CCN}$ (via condensation of secondary 

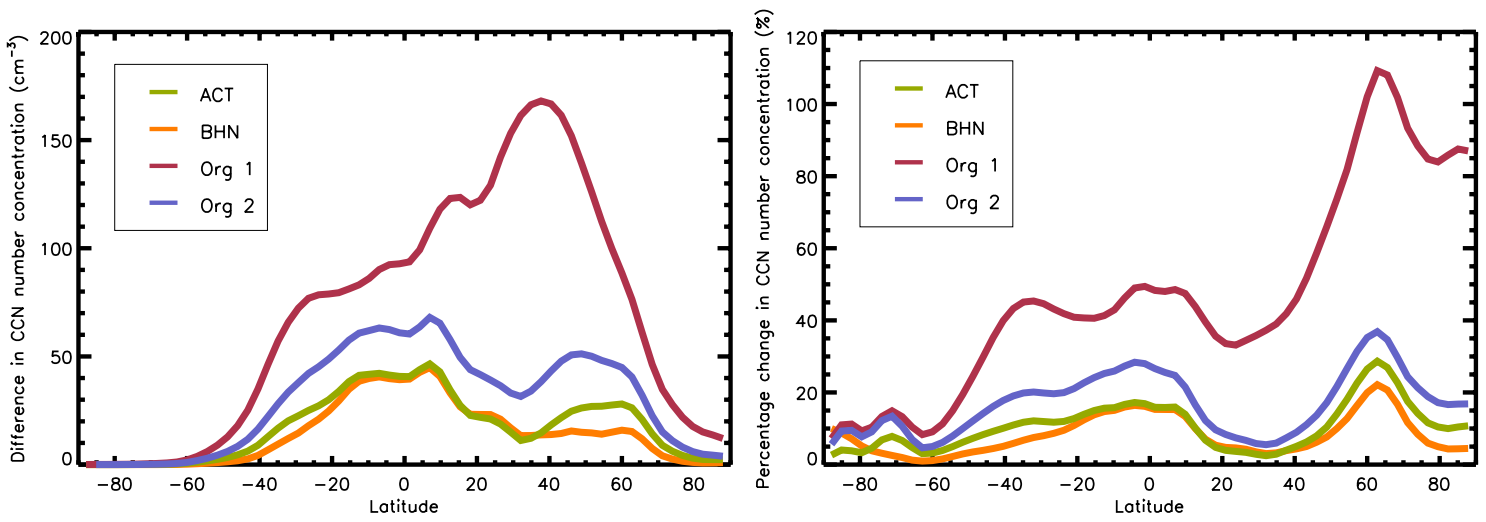

Fig. 3. Annual mean absolute change in surface $\mathrm{CCN}$ number concentration (left) and percentage change (right) at $0.2 \%$ supersaturation for four particle formation mechanisms: ACT (green), BHN only (orange), Org1 (red) and Org2 (blue) from the emission of monoterpenes only.

organic material) becomes limited by the enhanced condensation sink (due to larger particle sizes) and consequent suppression of new particle formation.

\subsection{Sensitivity to new particle formation}

The simulated contribution of SOA to global mean $\mathrm{CCN}$ concentrations depends strongly on the nucleation mechanism used in the model. Inclusion of an empirically derived particle activation mechanism within the boundary layer (i.e. ACT, Eq. 1) results in a greater absolute global annual mean change in $\mathrm{CCN}$ concentration due to monoterpene SOA $\left(+23.5 \mathrm{~cm}^{-3}\right.$; experiment 2$)$, when compared to the equivalent simulation using only BHN $\left(+20.3 \mathrm{~cm}^{-3}\right.$; experiment 14). This occurs because particles formed by the activation of $\mathrm{H}_{2} \mathrm{SO}_{4}$ clusters in the boundary layer are able to grow to $\mathrm{CCN}$-active sizes by the condensation of organic oxidation products and is particularly evident between 40 and $60^{\circ} \mathrm{N}$ (Fig. 3, left) where there is a strong contribution to total particle numbers from nucleation within the boundary layer (Merikanto et al., 2009). However, a similar annual global mean fractional $\mathrm{CCN}$ change $(+10.4 \%)$ due to monoterpene SOA is simulated in each case, owing to the higher background CCN concentration when the ACT mechanism is used.

When monoterpene oxidation products are allowed to participate in the very early stages of new particle formation (experiments 15 to 18), the contribution of biogenic SOA to $\mathrm{CCN}$ concentrations is substantially greater, increasing the global annual mean by $15.5 \%$ for Org 2 and $45.2 \%$ for Org 1 . The large increase in $\mathrm{CCN}$ concentrations when the Org1 mechanism is used can be attributed to the fact that in the absence of BVOC emissions, new particle formation in the boundary layer does not occur. In a test simulation, the value for $d^{*}$ in the $\operatorname{Org} 1$ experiments was reduced from $1.5 \mathrm{~nm}$ to $0.8 \mathrm{~nm}$ (to match ACT but not intended to represent a real scenario). This reduced the percentage increase in global annual mean $\mathrm{CCN}$ concentration (upon inclusion of biogenic
SOA) from $45.2 \%$ to $35.9 \%$, indicating that most of the enhancement in $\mathrm{CCN}$ concentration comes from the inclusion of organics in the nucleation rate itself, but some is due to the increased survival probability of newly formed particles associated with assuming a larger value for $d^{*}$. With this mechanism, the peak annual mean absolute increase in $\mathrm{CCN}$ concentration occurs at approximately $40^{\circ} \mathrm{N}$ (Fig. 3, left) due to large $\mathrm{CCN}$ increases simulated over south-east USA, Europe and China, regions of high monoterpene emission during the NH summer. Substantial fractional increases (over $100 \%$ ) are simulated in regions where high monoterpene emissions combine with low background aerosol number concentrations, such as the boreal regions of northern Russia and Canada (Fig. 3, right).

\section{Comparison to observations}

The simulated seasonal cycle in the number concentration of particles with dry diameter greater than $80 \mathrm{~nm}\left(\mathrm{~N}_{80}\right)$ was compared against multi-annual monthly mean observations at three forested sites: Hyytiälä, Finland from 1996 to 2006 (Kulmala et al., 1998b, 2001a), Pallas, Finland from 2000 to 2011 (Hatakka et al., 2003; Komppula et al., 2003), and Aspvreten, Sweden from 2005 to 2007 (Tunved et al., 2004b). These locations were chosen since they are relatively remote from anthropogenic aerosol sources and are in regions with substantial BVOC emissions. We chose to evaluate $\mathrm{N}_{80}$ concentrations since these match particles of $\mathrm{CCN}$ relevant size. Although $\mathrm{N}_{80}$ does not take into account the composition or solubility of the particles, long-term observations of CCN are not yet available at locations suitable for this study. Observations were taken from the EBAS database (available at http://ebas.nilu.no) and monthly mean model values are bilinearly interpolated to each location.

Table 3 gives, for a selection of our experiments, the correlation coefficient $(R)$ between simulated and observed monthly mean $\mathrm{N}_{80}$ concentrations at each site, and Fig. 4 
Table 3. Pearson correlation coefficient $(R)$ between multi-annual monthly mean observed and simulated monthly mean $\mathrm{N}_{80}$ concentrations. The normalised mean bias (NMB, \%) in surface CCN concentration between model and observations is also given for each simulation. The simulation with the best correlation at each location, or smallest NMB, is highlighted in bold.

\begin{tabular}{|c|c|c|c|c|c|c|}
\hline \multirow[b]{2}{*}{ Simulation } & & \multirow[b]{2}{*}{ Expt. no. } & \multicolumn{3}{|c|}{ Pearson correlation coefficient $(R)$} & \multirow[b]{2}{*}{$\begin{array}{r}\text { NMB } \\
(\%) \\
\text { against } \\
\text { subset of } \\
\text { CCN dataset }\end{array}$} \\
\hline & & & $\begin{array}{r}\text { Hyytiälä, Finland; } \\
\text { typical background for } \\
\text { high-latitude Europe; forest } \\
\text { location but influenced by } \\
\text { European pollution } \\
{\left[24.3^{\circ} \mathrm{E}, 61.9^{\circ} \mathrm{N}\right]}\end{array}$ & $\begin{array}{r}\text { Aspvreten, } \\
\text { Sweden; } \\
\text { boreal forest } \\
\text { location, mid-Sweden } \\
{\left[17.4^{\circ} \mathrm{E}, 58.8^{\circ} \mathrm{N}\right]}\end{array}$ & $\begin{array}{r}\text { Pallas, Finland; } \\
\text { very remote location } \\
\text { at northern border of } \\
\text { boreal zone } \\
{\left[24.1^{\circ} \mathrm{E}, 68.0^{\circ} \mathrm{N}\right]}\end{array}$ & \\
\hline \multirow{8}{*}{ ACT } & No SOA & 1 & 0.31 & 0.13 & 0.13 & -44.4 \\
\hline & $0.5 \times \mathrm{SOA}$ & 5 & 0.42 & 0.22 & 0.36 & -16.4 \\
\hline & SOA & 4 & 0.44 & 0.22 & 0.40 & -16.0 \\
\hline & $2 \times \mathrm{SOA}$ & 6 & 0.41 & 0.19 & 0.35 & -16.7 \\
\hline & $5 \times \mathrm{SOA}$ & 7 & 0.26 & 0.06 & 0.15 & -17.2 \\
\hline & No ageing by SOA & 8 & 0.44 & 0.21 & 0.42 & -40.5 \\
\hline & Fast ageing & 10 & 0.44 & 0.19 & 0.40 & -16.5 \\
\hline & Pri. Carb. small & 12 & 0.50 & 0.33 & 0.35 & +48.2 \\
\hline \multirow{2}{*}{ Org 1} & No SOA & 15 & 0.09 & -0.15 & -0.04 & -48.6 \\
\hline & SOA & 16 & 0.61 & 0.46 & 0.60 & +16.9 \\
\hline \multirow{2}{*}{ Org2 } & No SOA & 17 & 0.37 & 0.16 & 0.14 & -26.6 \\
\hline & SOA & 18 & 0.60 & 0.43 & 0.57 & +20.8 \\
\hline
\end{tabular}

shows the observed and simulated seasonal cycle at Hyytiälä and Pallas. A pronounced seasonal cycle in $\mathrm{N}_{80}$ is observed at these locations, with summertime (JJA) concentrations a factor of two greater than wintertime (DJF) concentrations. Without biogenic SOA, summertime $\mathrm{N}_{80}$ concentrations are under-predicted (dotted lines in Fig. 4) and simulations do not capture the seasonal cycle; the maximum correlation coefficient at Hyytiälä is 0.37 (Org2), 0.16 at Aspvreten (Org2), and 0.14 at Pallas (Org2). The inclusion of biogenic SOA improves the correlation between simulated and observed values for each set of simulations at all three locations, primarily by increasing summertime $\mathrm{N}_{80}$ concentrations.

When the ACT mechanism is used, increasing the yield of SOA production (experiments 6 and 7) reduces the correlation coefficient at all three sites, when compared to the standard yield simulation (experiment 4). This occurs because, at Hyytiälä for example, $\mathrm{N}_{80}$ concentrations simulated between June and September with the higher yields, are lower than simulated with the standard yield (not shown). During the summer months when BVOC emissions are highest, increasing SOA formation enhances the simulated condensation sink, suppressing new particle formation and growth of particles up to $80 \mathrm{~nm}$. Varying the ageing of non-hydrophilic particles (experiments 8 and 10) has little impact on seasonal cycles in $\mathrm{N}_{80}$ since both hydrophilic and non-hydrophilic particles contribute to the $\mathrm{N}_{80}$ concentration. The seasonal cycle is captured best when monoterpene oxidation products are included in the particle formation rate (red lines in Fig. 4), with the Org 1 mechanism giving the best correlation at all three locations (0.61 at Hyytiälä, 0.46 at Aspvreten and 0.60 at Pallas).
We also compared simulated surface-level CCN concentrations to a subset of the CCN data set compiled by Spracklen et al. (2011a). The treatment of primary carbonaceous emissions has been shown to strongly influence particle number concentrations and aerosol size distributions simulated by global aerosol microphysics models (Reddington et al., 2011; Spracklen et al., 2011a). We therefore compared against measurements filtered to minimise the influence of these particles: that is, data for terrestrial locations with a simulated present-day / pre-industrial $\mathrm{CCN}$ concentration ratio (calculated from $[\mathrm{CCN}]_{\text {expt. } 4} /{ }[\mathrm{CCN}]_{\text {expt. } 20}$ ) less than 2 , during times when the site was reported to be unaffected by wildfire emissions. This subset of data contained 25 observations (each representing a time-weighted mean CCN concentration from a sampling period of days to weeks) from the six locations detailed in Table 4. Relative uncertainties in the observational data set all lie in the range $\pm 5-40 \%$, but most within $\pm 10-20 \%$. CCN concentrations from the model were calculated for each of the six locations using the supersaturation at which the observations were recorded.

Table 3 reports the normalised mean bias (NMB) between observed and simulated CCN concentrations calculated according to Eq. (6) where $S_{i}$ are $\mathrm{CCN}$ number concentrations simulated by the model, and $O_{i}$ are observed CCN number concentrations at each location, $i$.

$\mathrm{NMB}=100 \% \times \sum\left(S_{i}-O_{i}\right) \div \sum O_{i}$ 

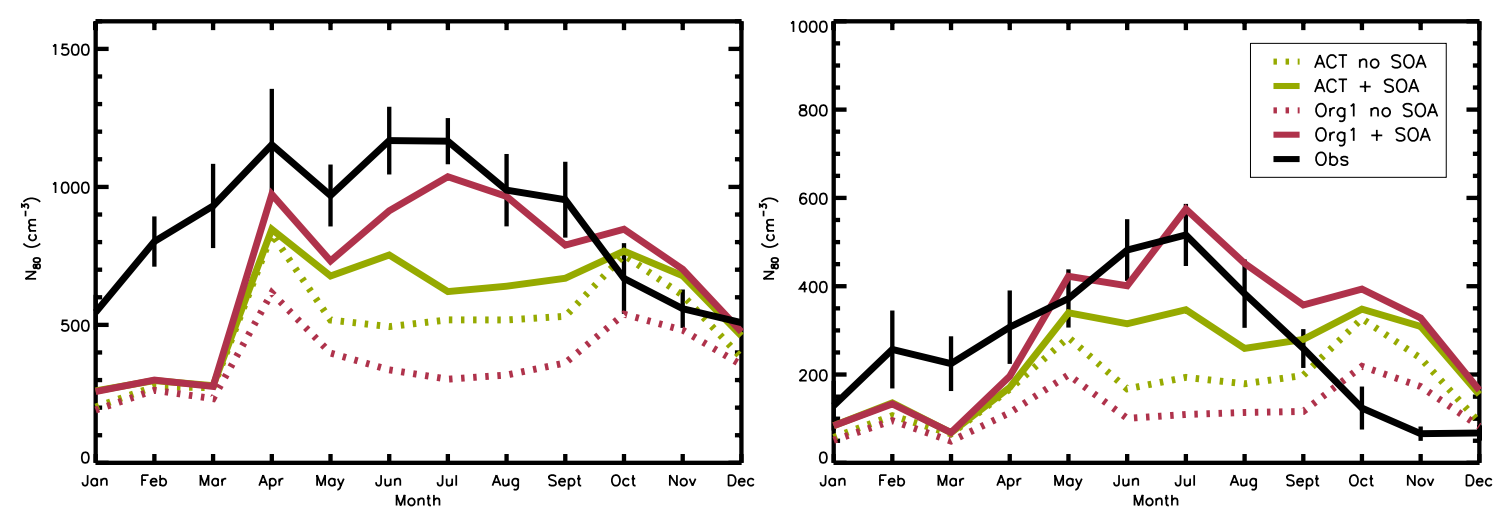

Fig. 4. Multi-annual monthly mean observed (black lines) seasonal cycle in $\mathrm{N}_{80}$ concentration at Hyytiälä (left) and Pallas (right); standard deviation of the observed monthly mean is indicated by the vertical black lines. $\mathrm{N}_{80}$ concentrations simulated using the ACT (green; expt. 1 and expt. 4) and Org1 (red; expt. 15 and expt. 16) nucleation mechanisms are shown with biogenic SOA (full lines) and without (dotted lines).
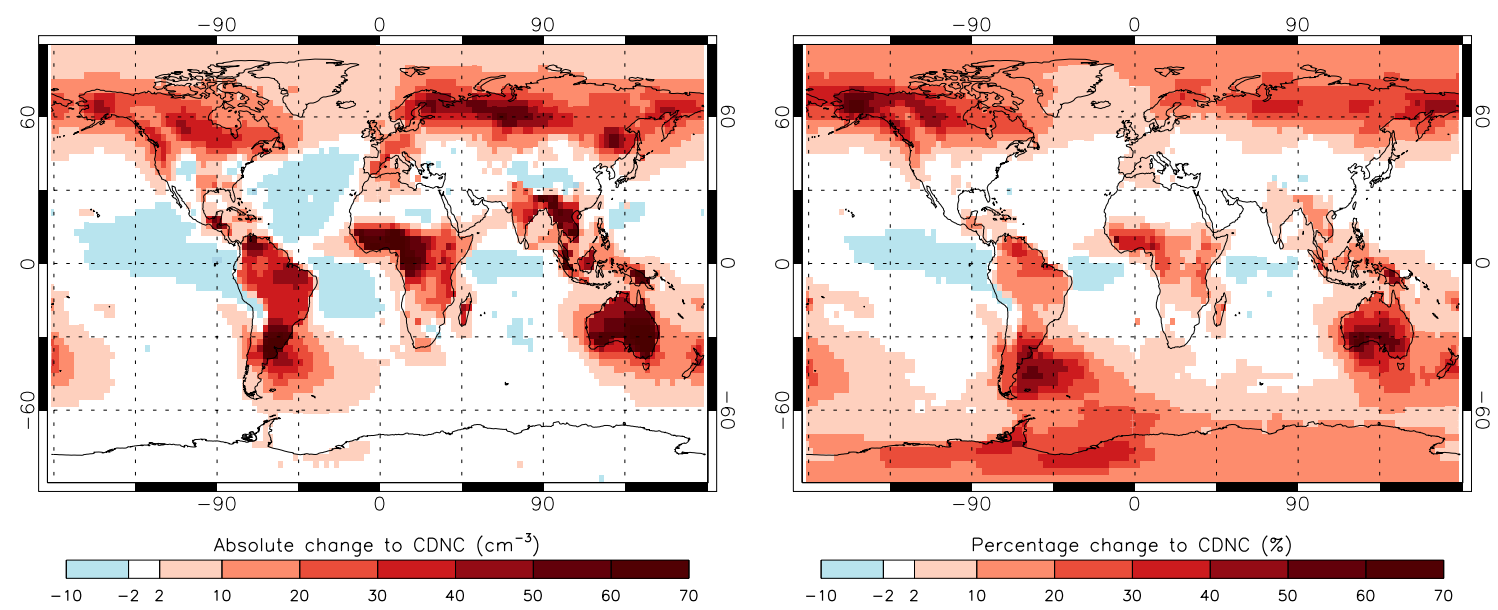

Fig. 5. Annual mean absolute (left) and percentage (right) change to CDNC due to biogenic SOA when the ACT nucleation mechanism is

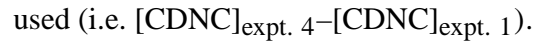

In the absence of biogenic SOA, CCN concentrations are under-predicted by the model (NMB $=-44.4 \%$ for ACT, $-48.6 \%$ for Org 1 and $-26.6 \%$ for Org2). Inclusion of biogenic SOA reduces the NMB at these locations, and to within the uncertainty associated with the observational data set, e.g. from $-44.4 \%$ to $-16.0 \%$ with ACT. Whilst the inclusion of monoterpene emissions in the particle formation rate (experiments 16 and 18) improved the correlation with the observed seasonal cycle at the European sites, simulations Org1 and Org2 lead to an over-prediction (NMB $=+16.9 \%$ for Org1 and $+20.0 \%$ for $\operatorname{Org} 2$ ) of CCN concentration, which is still, however, within the uncertainty of the measurements.

When biogenic SOA is included, but is not able to age nonhydrophilic particles to the hydrophilic distribution, $\mathrm{CCN}$ concentrations are under-predicted (NMB $=-40.5 \%$ ) suggesting that despite selecting for relatively pristine locations and times, the ageing of carbonaceous particles still contributes to local $\mathrm{CCN}$ concentrations. The faster rate of ageing makes little difference to the correlation (NMB $=-16.5 \%$, as compared to $-16.0 \%$ for the standard ageing), suggesting that the process of generating $\mathrm{CCN}$-active particles through physical ageing is not limited by the availability of condensable material in these locations. This is confirmed by the narrow range of NMB values obtained for experiments 4 to 7 ( $-16.0 \%$ to $-17.2 \%)$, over which the yield of SOA production is varied by a factor of 10 . When the smaller emission size for BC/POM particles is used (experiment 12 ), $\mathrm{CCN}$ concentrations are substantially overpredicted $(\mathrm{NMB}=+48.2 \%$ ), suggesting that this emission size generates too many $\mathrm{CCN}$-active particles in the presence of SOA. 
Table 4. Locations included in the subset of CCN observations taken from Spracklen et al. (2011a).

\begin{tabular}{lll}
\hline \multicolumn{2}{c}{ Location } & Reference \\
\hline Balbina, Amazon Basin & $59.4^{\circ} \mathrm{W}, 1.9^{\circ} \mathrm{S}$ & Roberts et al. (2001) \\
Rondonia, Amazon Basin & $61.9^{\circ} \mathrm{W}, 10.9^{\circ} \mathrm{S}$ & Williams et al. (2002) \\
Amazon Basin & $73^{\circ} \mathrm{W}, 5^{\circ} \mathrm{S}$ and $63^{\circ} \mathrm{W}, 12^{\circ} \mathrm{S}$ & Andreae et al. (2004) \\
Fazenda Nossa, Amazon Basin & $62.35^{\circ} \mathrm{W}, 10.8^{\circ} \mathrm{S}$ & Vestin et al. (2007) \\
Reno, USA & $119.8^{\circ} \mathrm{W}, 39.5^{\circ} \mathrm{N}$ & Hudson and Frisbie (1991) \\
Lauder, New Zealand & $169.7^{\circ} \mathrm{E}, 45^{\circ} \mathrm{S}$ & Delene and Deshler (2001) \\
\hline
\end{tabular}
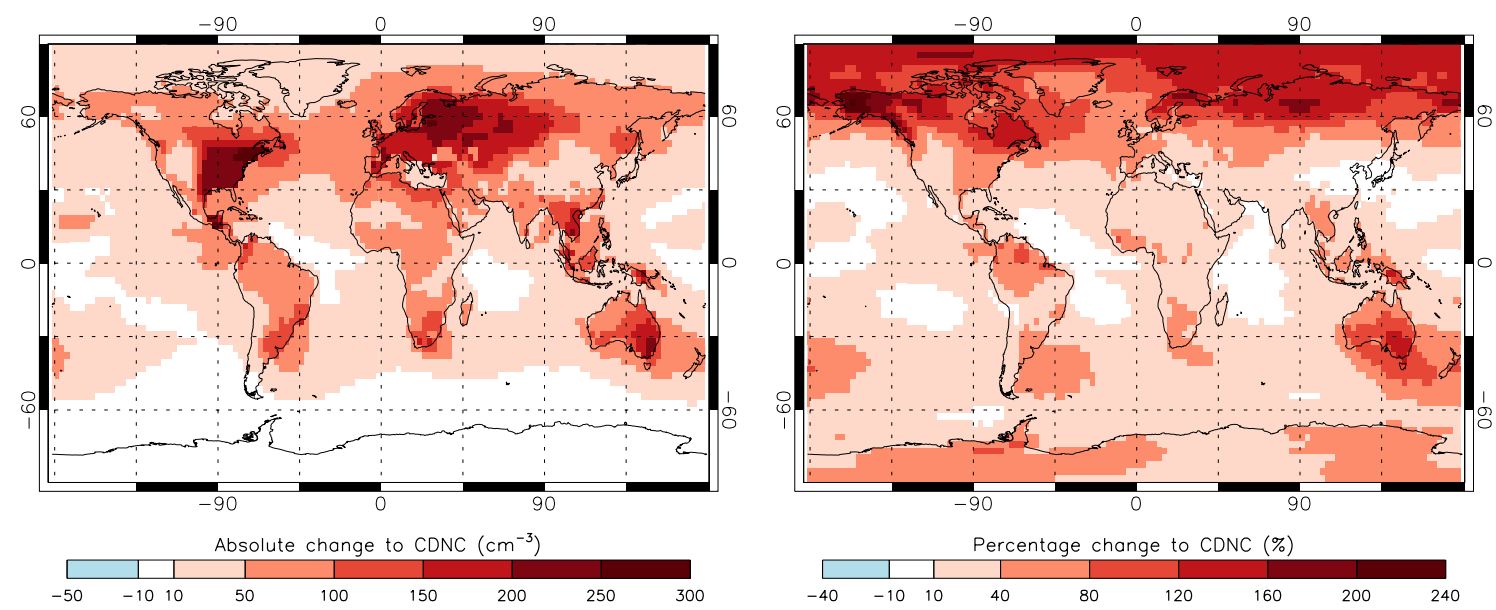

Fig. 6. Annual mean absolute (left) and percentage (right) change to CDNC due to biogenic SOA (monoterpenes only) when the Org1

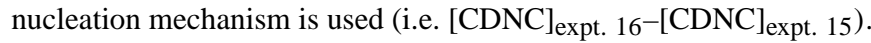

\section{Cloud droplet number concentrations}

We simulate that biogenic SOA increases the global annual mean CDNC by between $1.9 \%$ and $5.2 \%$ when the ACT nucleation mechanism is used (Table 2). Figure 5 shows the spatial distribution of the annual mean change in CDNC due to the presence of biogenic SOA, when the ACT mechanism is used and emissions of both monoterpenes and isoprene are included. Over most regions, perturbations to calculated CDNC follow the same spatial pattern as changes to $\mathrm{CCN}$ concentration. However, in regions with high preexisting aerosol concentrations, such as those heavily affected by biomass burning, activation of additional $\mathrm{CCN}$ to cloud droplets can become limited by competition for water vapour. This is evident over South America and western Africa, where the largest changes to CDNC (Fig. 5) do not coincide spatially with the largest changes to $\mathrm{CCN}$ (Fig. 1). As with CCN, relatively low absolute changes to CDNC in the SH can lead to high fractional changes over the oceans. In the boreal regions, the inclusion of biogenic SOA increases the annual mean CDNC by up to $70 \%$ due to very low background CDNC and therefore a high sensitivity to additional CCN. Small decreases $(<10 \%)$ in CDNC occur over the tropical oceans due to the decreases in $\mathrm{CCN}$ described in Sect. 3.1. As with CCN, including monoterpene oxida- tion products in the particle formation rate equation yields the greatest increase in CDNC due to biogenic SOA $(26.6 \%$ and $7.2 \%$ for Org 1 and Org2 respectively). Figure 6 shows the spatial distribution of the annual mean CDNC change when the Org1 mechanism is used; as with $\mathrm{CCN}$, large absolute increases are simulated at around $40^{\circ} \mathrm{N}$, whilst fractional increases in excess of $100 \%$ are simulated above $60^{\circ} \mathrm{N}$ (Fig. 3).

\section{Radiative effect of biogenic SOA}

We calculate a global mean DRE of between $-0.08 \mathrm{~W} \mathrm{~m}^{-2}$ and $-0.78 \mathrm{~W} \mathrm{~m}^{-2}$ for biogenic SOA in the present-day atmosphere (Table 2), with the spatial distribution of the effect for experiment 4 shown in Fig. 7 (left). Figure 8 (left) shows the sensitivity of the global annual mean DRE to the processes examined in this study. The magnitude of the DRE is highly sensitive to the amount of SOA (and therefore the amount of growth of particles) included in the simulation, with the global annual mean varying from $-0.09 \mathrm{~W} \mathrm{~m}^{-2}$ when the $\mathrm{SOA}$ production yield is halved (source of $18.5 \mathrm{Tg}(\mathrm{SOA}) \mathrm{a}^{-1}$ ), to $-0.78 \mathrm{~W} \mathrm{~m}^{-2}$ when the yield is increased by a factor of 5 (source of 185.1 $\left.\mathrm{Tg}(\mathrm{SOA}) \mathrm{a}^{-1}\right)$. As such, the DRE is strongest over the tropics where BVOC emissions are highest (Fig. 7, left). 

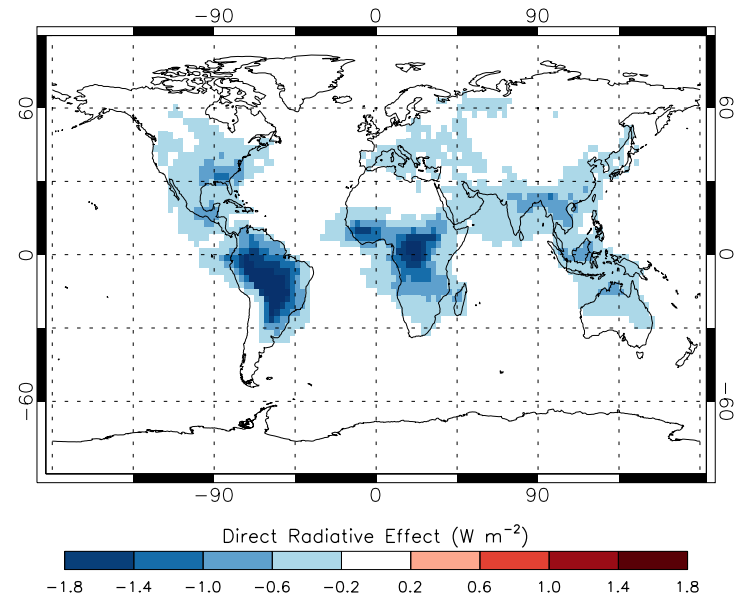

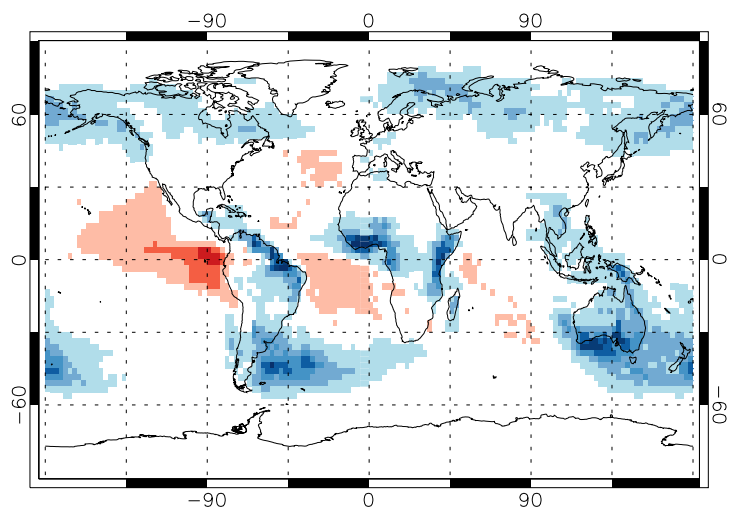

First Aerosol Indirect Effect $\left(\mathrm{W} \mathrm{m}^{-2}\right)$

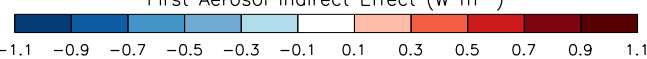

Fig. 7. Annual mean all-sky DRE (left), and first AIE (right) associated with the perturbation in cloud droplet number concentration, due to biogenic SOA (expt. 4) relative to an equivalent simulation with no biogenic SOA (expt. 1).

Changes in the nucleation mechanism result in little variability in the DRE (range $-0.08 \mathrm{~W} \mathrm{~m}^{-2}$ to $-0.10 \mathrm{~W} \mathrm{~m}^{-2}$ ). The large increase in the number of nucleated particles and $\mathrm{CCN}$ simulated with the organic nucleation mechanisms is less important for the direct effect as these particles are too small to influence the path of incoming solar radiation. The DREs simulated by Rap et al. (2013) and O'Donnell et al. (2011) lie within the range we calculate here. Goto et al. (2008) calculated a smaller DRE of $-0.01 \mathrm{~W} \mathrm{~m}^{-2}$, but included less SOA $\left(\sim 7 \mathrm{Tg}(\mathrm{SOA}) \mathrm{a}^{-1}\right)$, and used a mass-only aerosol model which does not simulate the growth of particles associated with the condensation of secondary organic material.

We calculate that in the present-day atmosphere, biogenic SOA exerts a global annual mean first AIE of between +0.01 and $-0.77 \mathrm{~W} \mathrm{~m}^{-2}$ (Table 2). Figure 7 (right) shows the spatial distribution in the first AIE due to biogenic SOA in a simulation using the ACT mechanism (experiment 4). A negative first AIE occurs in locations experiencing a large relative increase in CDNC (e.g. boreal Asia), or a modest increase in CDNC coinciding with a high fraction of low level cloud cover (e.g. SH oceans). A positive first AIE occurs in locations where a small decrease in CDNC (Fig. 5) coincides with very high cloud fraction, such as the western coasts of central America and Africa (Fig. 7, right).

Figure 8 (right) summarises the sensitivity of the global annual mean first AIE to the processes examined in this study. The simulated global annual mean first AIE is most sensitive to the nucleation mechanism used in the model (global annual mean range $-0.05 \mathrm{~W} \mathrm{~m}^{-2}$ to $-0.77 \mathrm{~W} \mathrm{~m}^{-2}$ ); the inclusion of monoterpene oxidation products in the particle formation rate results in greater $\mathrm{CCN}$ and $\mathrm{CDNC}$ increases, and therefore a more negative first AIE, than either the BHN or ACT mechanisms. As with the ACT simulation, both organic nucleation mechanisms generate a negative first AIE over the oceans between $30^{\circ} \mathrm{S}$ and $50^{\circ} \mathrm{S}$, but $\operatorname{Org} 1$ in particular also yields large negative forcings in the $\mathrm{NH}$ due to high fractional $\mathrm{CCN}$ and $\mathrm{CDNC}$ changes between $40^{\circ} \mathrm{N}$ and $60^{\circ} \mathrm{N}$ (Fig. 3).

Using the smaller size characteristics for primary carbonaceous emissions gives greater $\mathrm{CCN}$ and $\mathrm{CDNC}$ increases due to biogenic SOA, and subsequently a more substantial first AIE of $-0.12 \mathrm{~W} \mathrm{~m}^{-2}$. When secondary organic material is not able to age non-hydrophilic particles to the hydrophilic distribution, the global annual mean first AIE is reduced to $-0.02 \mathrm{~W} \mathrm{~m}^{-2}$, due to smaller increases in CCN and CDNC. Whilst increasing the yield of SOA production gives a greater global annual mean fractional increase in CDNC (Table 2), the increased yield enhances negative CDNC changes in regions with very high cloud fraction, so the first AIE becomes less negative (e.g. $-0.04 \mathrm{~W} \mathrm{~m}^{-2}$ when the SOA yield is doubled).

Over boreal forests, regional annual mean first AIEs of between $-0.1 \mathrm{~W} \mathrm{~m}^{-2}$ and $-0.5 \mathrm{~W} \mathrm{~m}^{-2}$ are calculated with the ACT mechanism (Fig. 7, right) and between $-0.1 \mathrm{~W} \mathrm{~m}^{-2}$ and $-1.5 \mathrm{~W} \mathrm{~m}^{-2}$ with the Org 1 nucleation mechanism.

As illustrated in Fig. 9, much of the boreal region experiences a summertime (JJA) mean first AIE of between $-1 \mathrm{~W} \mathrm{~m}^{-2}$ and $-5 \mathrm{Wm}^{-2}$, when the Org1 mechanism is used, matching the large cooling effect over these forest regions calculated by previous studies (Kurten et al., 2003; Spracklen et al., 2008a; Lihavainen et al., 2009). However, the strongest regional radiative effect (up to $-9 \mathrm{~W} \mathrm{~m}^{-2}$ ) is simulated over the North Atlantic ocean $\left(50-60^{\circ} \mathrm{N}\right)$ which, whilst experiencing a smaller CDNC increase than the land regions at the same latitude, has higher cloud coverage in the ISCCP data set (i.e. cloud fraction of $50-70 \%$ as compared to $0-30 \%$ over the land). In agreement with Lihavainen et al. (2009) we find that over the boreal region, the simulated first AIE is substantially greater than the DRE (Fig. 7).

The AIE from monoterpene SOA $\left(-0.19 \mathrm{~W} \mathrm{~m}^{-2}\right)$ estimated by Goto et al. (2008) lies within the range of first AIE we calculate here. The first AIE of $-0.02 \mathrm{~W} \mathrm{~m}^{-2}$ calculated 

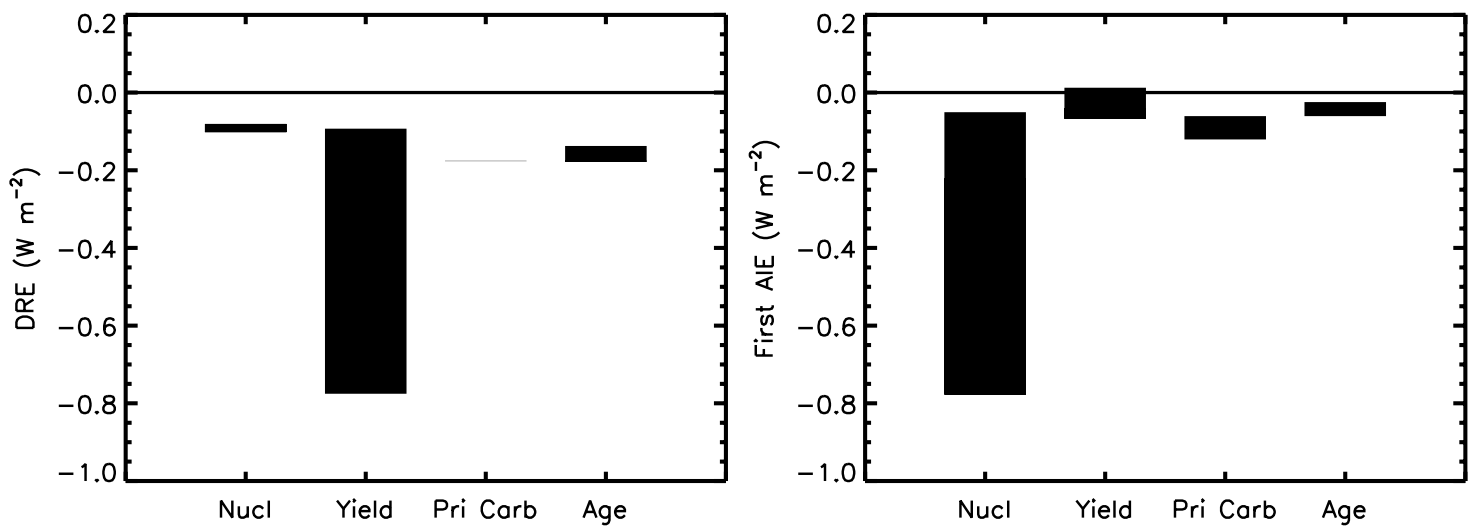

Fig. 8. Variation in global annual mean DRE (left) and first AIE (right) of biogenic SOA associated with several parameters; black bars indicate the range of values obtained for each set of experiments: Nucl (nucleation mechanism; expt. 2, 14, 16, 18), Yield (SOA yield; expt. 4, 5, 6, 7), Pri Carb (primary carbonaceous emission size; expt. 4, 12), Age (physical ageing; expt. 4, 8, 10).

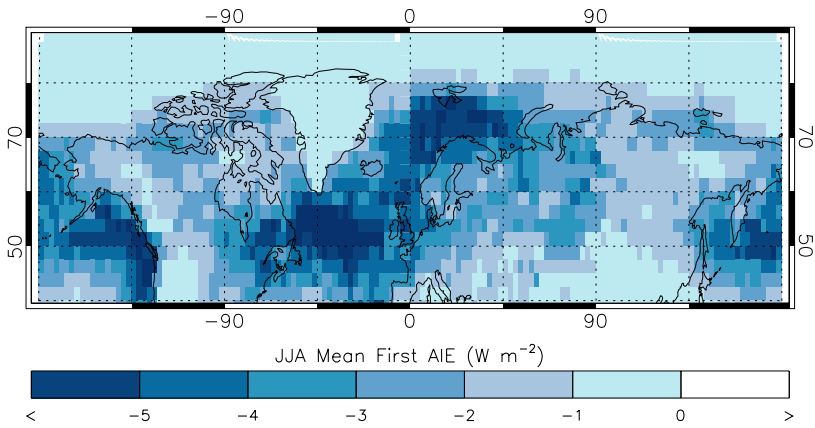

Fig. 9. Summertime (JJA) mean first AIE from monoterpene SOA when the Org 1 nucleation mechanism is used (expt. 16).

by Rap et al. (2013) was for a GLOMAP simulation using BHN (as in our experiment 14) and required only one soluble monolayer to transfer non-hydrophilic particles to the hydrophilic distribution (as in our experiment 10), and is in line with the first AIEs calculated here. O'Donnell et al. (2011) simulated a positive AIE $\left(+0.23 \mathrm{~W} \mathrm{~m}^{-2}\right)$ for all SOA (i.e. biogenic plus anthropogenic), which lies outside our range (between +0.01 and $-0.77 \mathrm{~W} \mathrm{~m}^{-2}$ ). The positive AIE simulated by O'Donnell et al. (2011), may be caused by the secondary organic material being distributed preferentially amongst larger size particles (i.e. those already large enough to act as $\mathrm{CCN}$ ), resulting in a decrease in global mean CDNC. We examine the sensitivity of the biogenic SOA AIE to assumptions concerning the part of the aerosol size distribution to which SOA is added (i.e. volatility treatment of the condensable material), in a further publication (Scott et al., 2014).

There is a large difference between the spatial pattern of the DRE and first AIE due to biogenic SOA. This is mainly driven by the distribution of clouds since a high cloud fraction will suppress any potential DRE from changes to par- ticle number and size below, but will enhance any potential AIE from changes to particle number and size. Consequently, the DRE tends to be stronger over the relatively less cloudy (based on the ISCCP clouds for the year 2000) land regions and the first AIE tends to be stronger over the relatively more cloudy ocean regions. For example, in the ACT simulation shown in Fig. 7, the DRE is more than a factor of 5 greater than the first AIE over central Africa and South America, whereas the first AIE is more than a factor of 5 greater than the DRE over high-latitude Northern and Southern Hemisphere ocean regions.

\section{Sensitivity of the radiative effect of biogenic SOA to anthropogenic emissions}

Primary particulate (POM and $\mathrm{BC})$ and gas-phase $\left(\mathrm{SO}_{2}\right)$ emissions from anthropogenic sources were much lower in 1750 than in the present day. These lower emissions result in lower simulated background (i.e. in the absence of biogenic SOA) concentrations of $\mathrm{CCN}$. The radiative effect of biogenic SOA may therefore have been different in a pre-industrial atmosphere. To explore this possibility we simulated the impact of biogenic SOA in an atmosphere with 1750 anthropogenic emissions (experiments 19 and 20; ACT_1750). Including biogenic SOA in a pre-industrial atmosphere yields a lower absolute change in $\mathrm{CCN}$ number concentration than in the present day. This lower absolute change is due to fewer ultrafine particles being available (from nucleation and primary sources) for growth to $\mathrm{CCN}$ sizes, or ageing, by the secondary organic material. Despite the lower absolute change, the inclusion of biogenic SOA results in a higher fractional change of $+23.2 \%$ (Table 2), due to lower background $\mathrm{CCN}$ concentrations in the preindustrial atmosphere. This increased fractional change in CCN, combined with lower background CDNC, results in a greater perturbation to $\mathrm{CDNC}$ due to biogenic SOA in a 

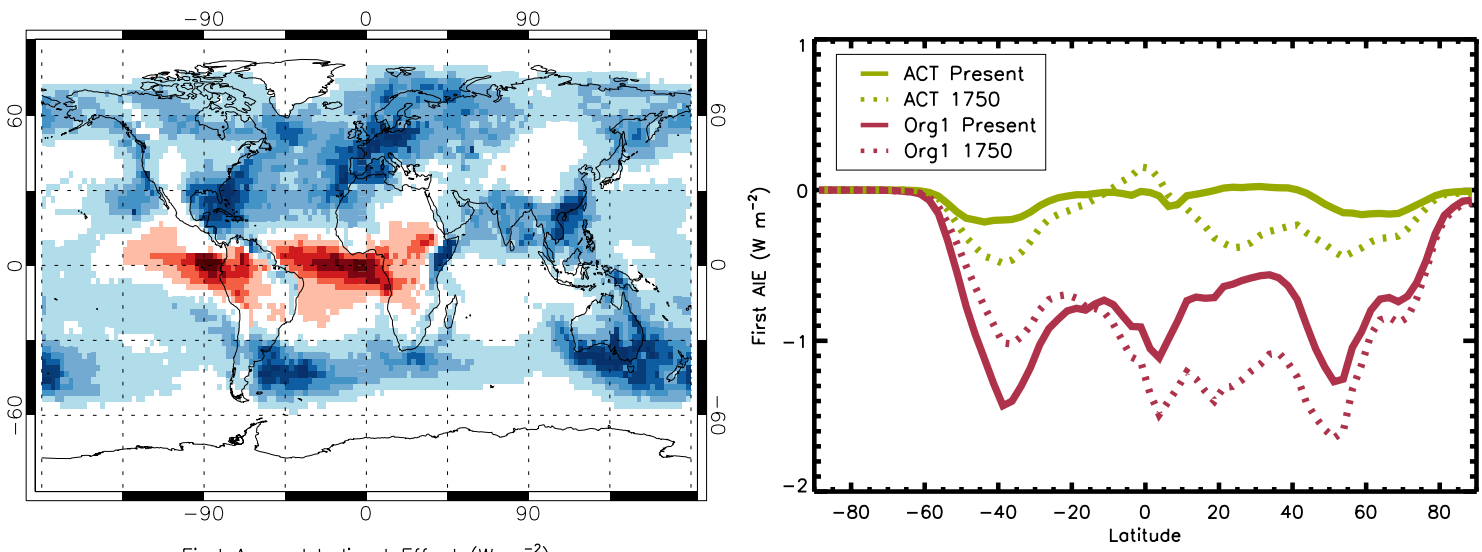

First Aerosol Indirect Effect $\left(\mathrm{W} \mathrm{m}^{-2}\right)$

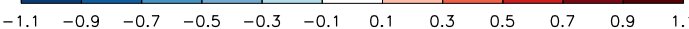

Fig. 10. Left: annual mean first AIE from biogenic SOA when anthropogenic emissions from 1750 are included in GLOMAP. Right: annual zonal mean first AIE from biogenic SOA in present-day (solid lines) and pre-industrial (dashed lines) simulations when the ACT (green) and Org1 (red) nucleation mechanisms are used.

pre-industrial atmosphere (global annual mean $+12.6 \%$, as compared to $+4.4 \%$ in the present day).

Since the fractional change in CDNC constrains the first AIE (Eq. 5), a more substantial indirect effect of $-0.19 \mathrm{~W} \mathrm{~m}^{-2}$ is simulated with 1750 anthropogenic emissions (experiment 20; ACT_1750) compared to $-0.06 \mathrm{~W} \mathrm{~m}^{-2}$ with the same model setup in the present day. Regions of both positive and negative change in CDNC are enhanced by the lower background concentration, so this global mean radiative effect represents a combination of $\mathrm{NH}$ land and $\mathrm{SH}$ ocean regions experiencing a more negative first AIE and tropical oceans experiencing a more substantial positive first AIE (Fig. 10), as compared to an equivalent simulation using present-day anthropogenic emissions (Fig. 7, right).

The global mean first AIE obtained using the Org 1 particle formation mechanism (experiment 22; Org1_1750) is also enhanced in the 1750 atmosphere $\left(-0.95 \mathrm{~W} \mathrm{~m}^{-2}\right.$ as compared to $-0.77 \mathrm{~W} \mathrm{~m}^{-2}$ in the present day). The annual mean first AIE is more negative at most latitudes, but at $30-50^{\circ} \mathrm{S}$, the radiative effect is stronger in the present-day simulation (solid red line in Fig. 10, right) due to higher $\mathrm{SO}_{2}$ emissions in southern Africa and Australia, required to generate the $\mathrm{H}_{2} \mathrm{SO}_{4}$ needed to form new particles using the $\mathrm{Org} 1$ nucleation mechanism.

Increasing the SOA yield when 1750 anthropogenic emissions are used results in a greater fractional enhancement to $\mathrm{CCN}$ than when present-day anthropogenic emissions are used (Fig. 11, left). This enhanced CCN sensitivity translates into a greater CDNC and first AIE sensitivity and has implications for the first aerosol indirect radiative forcing (RF) due to anthropogenic aerosol emissions. To test this, we calculate an anthropogenic first indirect RF since 1750, by setting $\mathrm{CDNC}_{1}$ in Eq. (5) to the present day, and
$\mathrm{CDNC}_{2}$ to the value obtained from a simulation using anthropogenic emissions from 1750 . We find that the first aerosol indirect RF from anthropogenic emission changes (1750 to present) is $-1.16 \mathrm{~W} \mathrm{~m}^{-2}$ when we assume a low source of biogenic SOA $\left(18.5 \mathrm{Tg}(\mathrm{SOA}) \mathrm{a}^{-1}\right)$ but decreases in absolute value to $-1.10 \mathrm{~W} \mathrm{~m}^{-2}$ when we assume a large source $\left(185.1 \mathrm{Tg}(\mathrm{SOA}) \mathrm{a}^{-1}\right)$ (purple circles in Fig. 11, right).

If the Org1 mechanism is used in both present-day and 1750 simulations (red circle in Fig. 11, right), the calculated aerosol indirect $\mathrm{RF}$ is $-1.04 \mathrm{~W} \mathrm{~m}^{-2}$, that is $0.12 \mathrm{~W} \mathrm{~m}^{-2}$ smaller than that derived using the ACT mechanism and an equivalent SOA source strength. The variation in first indirect anthropogenic RF, due to uncertainties in SOA yield and nucleation mechanism, highlights the need to understand the baseline pre-industrial atmosphere and the magnitude of preexisting natural radiative effects in order to constrain the RFs due to human activities. A previous study demonstrated that uncertainty in volcanic $\mathrm{SO}_{2}$ emissions plays a similar role in driving uncertainty in the anthropogenic first aerosol indirect RF (Schmidt et al., 2012).

By contrast, the DRE of biogenic SOA is less sensitive to the presence of anthropogenic emissions. When the ACT mechanism is used, the same DRE is simulated with presentday and 1750 anthropogenic emissions $\left(-0.18 \mathrm{~W} \mathrm{~m}^{-2}\right)$. When the Org 1 mechanism is used, DREs of $-0.08 \mathrm{~W} \mathrm{~m}^{-2}$ and $-0.12 \mathrm{~W} \mathrm{~m}^{-2}$ are simulated with present-day and 1750 anthropogenic emissions respectively. The DRE is slightly enhanced in the 1750 atmosphere because there is less organically mediated new particle formation than in the present day $\left(\Delta \mathrm{N}_{3}\right.$ is $+643.0 \mathrm{~cm}^{-3}$ in the present day, and $+437.3 \mathrm{~cm}^{-3}$ in the 1750 atmosphere), due to lower $\mathrm{SO}_{2}$ emissions. As a result, there are fewer nucleation mode particles requiring condensable material for growth in the 1750 atmosphere, and a greater proportion of the secondary organic 

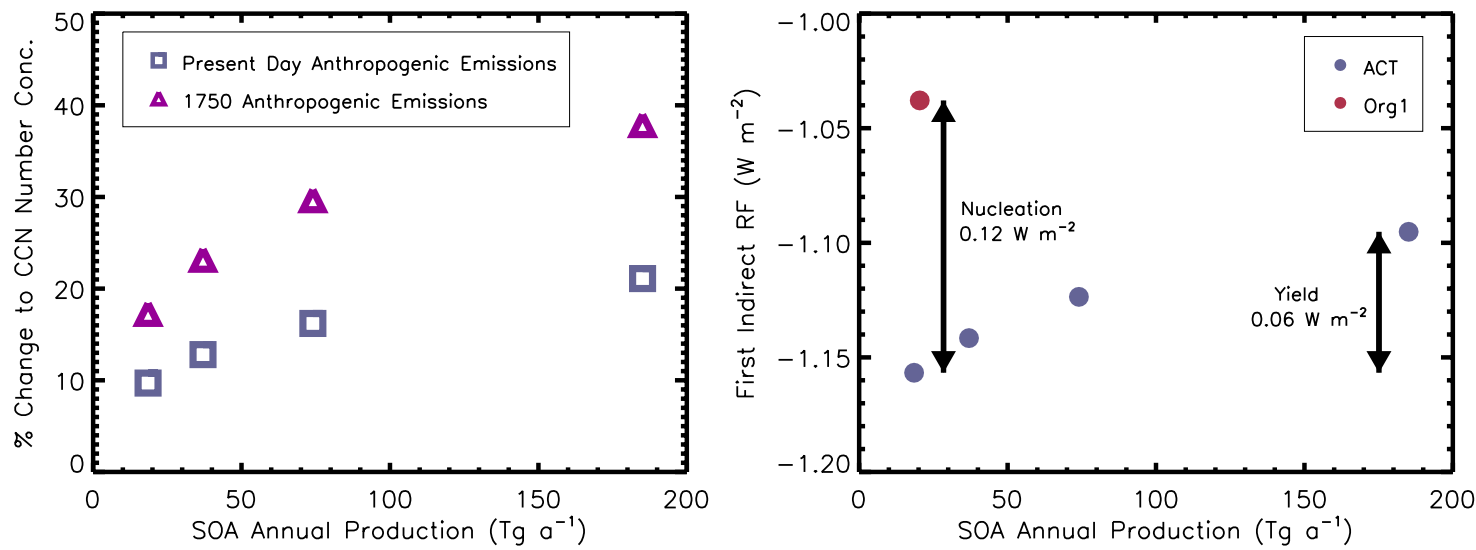

Fig. 11. Left: percentage change to global annual mean CCN concentration when biogenic SOA is included, simulated using the ACT nucleation mechanism at four different SOA production yields, with present-day (squares) and pre-industrial (triangles) anthropogenic emissions. Right: anthropogenic first aerosol indirect RF from 1750 to present-day, simulated using the ACT nucleation mechanism at four different yields for SOA production (purple circles), and using the Org1 nucleation mechanism with standard SOA production yield (red circle). Arrows highlight the RF sensitivity to assumptions about SOA yield and nucleation mechanism.

material is distributed towards larger size particles which are capable of interacting with incoming radiation.

\section{Summary and conclusions}

We used a global aerosol microphysics model (GLOMAP) and an offline radiative transfer model to quantify the impact of biogenic SOA on CCN concentrations and CDNC, and the subsequent radiative implications.

In all present-day simulations, the global annual mean $\mathrm{CCN}$ concentration increases (by between $3.6 \%$ and $45.2 \%$ ) when biogenic SOA is included. In the absence of organically mediated nucleation, most of the simulated increase in $\mathrm{CCN}$ number concentration occurs due to physical ageing, and subsequent growth, of non-hydrophilic particles originating from wildfire and carbonaceous combustion. However, when monoterpene oxidation products affect the new particle formation rate, $\mathrm{CCN}$ concentrations are mostly perturbed by the growth of newly formed particles to CCNactive sizes. Similarly, at around $60^{\circ} \mathrm{N}$, where monoterpene emissions are high during the NH summer months and background particle concentrations are low, a greater proportion of the CCN increase is associated with the growth of smaller particles. Regional decreases in $\mathrm{CCN}$ concentrations are simulated, in particular over the tropical oceans, due to enhanced nucleation scavenging of non-hydrophilic particles, and the suppression of upper tropospheric and boundary layer nucleation. The spatial changes to CDNC from the inclusion of biogenic SOA broadly match changes to $\mathrm{CCN}$ concentrations, with global annual mean increases ranging from $1.9 \%$ to $26.6 \%$. However, the magnitude of CDNC change becomes limited by competition for water vapour in highly polluted regions, such as those affected by biomass burning. The low sensitivity of CCN to the inclusion of biogenic SOA in experiments without organically mediated nucleation is consistent with the much larger parameter sensitivity study of Lee et al. (2013). In this sensitivity study, biogenic SOA production was varied between 5 and $360 \mathrm{Tg}(\mathrm{SOA}) \mathrm{a}^{-1}$, which resulted in a global mean $3 \%$ standard deviation in $\mathrm{CCN}$ concentration, with a maximum standard deviation of approximately $40 \%$ locally. Our results confirm the suggestion of Lee et al. (2013) that organically mediated nucleation would greatly increase the sensitivity of $\mathrm{CCN}$ to SOA.

The radiative effect attributed to biogenic SOA is uncertain. We calculate that biogenic SOA results in a present day global annual mean all-sky top-of-atmosphere DRE of between $-0.08 \mathrm{~W} \mathrm{~m}^{-2}$ and $-0.78 \mathrm{~W} \mathrm{~m}^{-2}$, and a first AIE of between $+0.01 \mathrm{~W} \mathrm{~m}^{-2}$ and $-0.77 \mathrm{~W} \mathrm{~m}^{-2}$. This range extends our previous estimates of $-0.13 \mathrm{~W} \mathrm{~m}^{-2}$ for the DRE and $-0.02 \mathrm{~W} \mathrm{~m}^{-2}$ for the first AIE of biogenic SOA (Rap et al., 2013). The DRE is most sensitive to the yield of SOA production and strongest in regions of high BVOC emission. Increasing or decreasing the yield of SOA production from the base case values reduces the agreement with observations of particle number greater than $80 \mathrm{~nm}$ diameter $\left(\mathrm{N}_{80}\right)$ at three forested locations (Table 3). Our best estimate of the DRE from biogenic SOA is therefore $-0.18 \mathrm{~W} \mathrm{~m}^{-2}$, consistent with a global production of $37 \mathrm{Tg}(\mathrm{SOA}) \mathrm{a}^{-1}$. The largest uncertainty in the first AIE of biogenic SOA comes from the representation of new particle formation in the boundary layer, specifically whether organic compounds contribute to the very early stages of new particle formation. Including the oxidation products of monoterpenes in the particle formation rate equation gives a first AIE from biogenic SOA up to 11 times greater than when sulphuric acid alone controls new particle formation. The best agreement between 


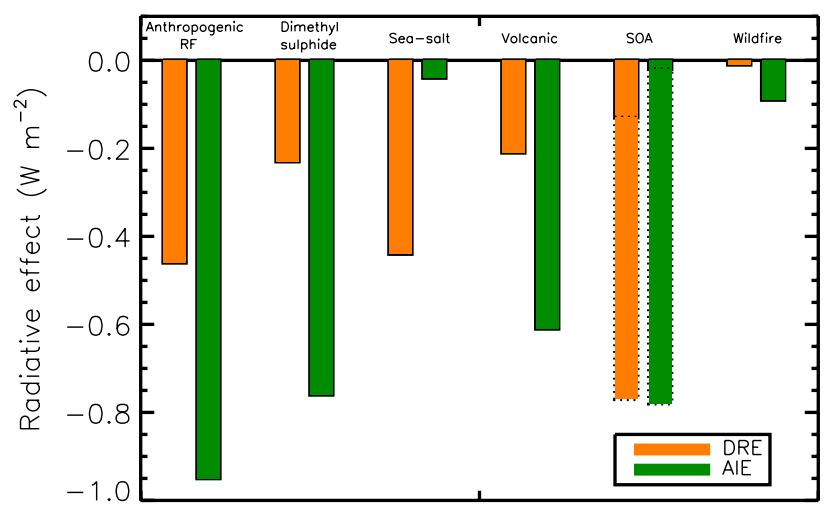

Fig. 12. Comparison of anthropogenic aerosol radiative forcing (RF) and the radiative effects (RE) calculated for natural aerosol sources. The REs for biogenic SOA (dotted bars) are from this study, and all other values are from Rap et al. (2013).

simulated and measured seasonal cycles in $\mathrm{N}_{80}$ is obtained when monoterpene oxidation products affect the new particle formation rate, suggesting that the magnitude of the global annual mean first AIE from biogenic SOA could lie towards the upper end of our estimated range of $-0.77 \mathrm{~W} \mathrm{~m}^{-2}$. The observations of $\mathrm{N}_{80}$ used here are restricted to boreal forest locations in northern Europe; long-term observations of $\mathrm{N}_{80}$ in other forest ecosystems will be required to give tighter constraints on the global radiative effect of biogenic SOA.

Figure 12 compares the radiative effect of biogenic SOA calculated here against the radiative effects of other natural aerosol sources and the anthropogenic aerosol radiative forcing. The radiative effects of natural aerosol sources are similar in magnitude to the anthropogenic aerosol RF, as has been previously documented (Rap et al., 2013). Our upper estimates of the radiative effects of biogenic SOA exceed the radiative effects of the other natural aerosol sources (DMS, volcanic sulphate, sea salt and wildfires) examined by Rap et al. (2013). Narrowing the large uncertainty in the radiative effect of biogenic SOA is therefore a prerequisite for a better understanding of the relative roles of natural aerosol in the climate system.

At high northern latitudes, monoterpene emissions from boreal forests result in a summertime regional first AIE of up to $-6 \mathrm{~W} \mathrm{~m}^{-2}$ over land, and $-9 \mathrm{~W} \mathrm{~m}^{-2}$ over ocean, when organic compounds influence the new particle formation rate (Org1 mechanism). Previous studies (Betts, 2000; Snyder et al., 2004; Bala et al., 2007; Davin and de Noblet-Ducoudré, 2010) suggest that the low land-surface albedo of boreal forests exerts a warming (i.e. positive radiative effect) on the climate which potentially outweighs the cooling effect (i.e. negative radiative effect) due to carbon storage by these forests. Follow-up work is required to examine the radiative effect of biogenic SOA in comparison to these other effects in order to quantify the overall climate impact of boreal forests.
When the present-day anthropogenic aerosol emissions in our simulations are replaced with those from 1750, the lower background aerosol concentrations result in a greater proportion of additional CCN becoming activated and therefore a more substantial first AIE from biogenic SOA in the preindustrial atmosphere $\left(-0.19 \mathrm{~W} \mathrm{~m}^{-2}\right.$ and $-0.95 \mathrm{~W} \mathrm{~m}^{-2}$ for ACT and Org1 respectively). As such, the first AIE from biogenic SOA in 1750 is more sensitive to changes in the amount of SOA generated and the nucleation mechanism used, adding uncertainties of $0.06 \mathrm{~W} \mathrm{~m}^{-2}$ and $0.12 \mathrm{~W} \mathrm{~m}^{-2}$ respectively to the magnitude of the first aerosol indirect $\mathrm{RF}$ from anthropogenic emissions since 1750 (Fig. 11, right). SOA formation from BVOCs may be enhanced by anthropogenic pollution (Heald et al., 2011; Hoyle et al., 2011; Spracklen et al., 2011b); consequently, global SOA formation may have been quite different in a pre-industrial atmosphere. We did not explore this coupling here, but the wide range of SOA production that we analysed is likely to cover both pre-industrial and present-day levels of SOA production.

As emissions of both biogenic and anthropogenic aerosol change in the future, our understanding of their effects and interactions will gain increasing importance. Emissions of BVOCs will be sensitive to future changes in climate (e.g. Lathière et al., 2005; Tunved et al., 2008; Paasonen et al., 2013), vegetation (Heald et al., 2008), and carbon dioxide concentrations (Heald et al., 2009; Pacifico et al., 2012). Additionally, changes in the spatial distribution of BVOC emissions are likely to be as important as the global magnitude of emissions, as has been shown for changes to oceanic DMS emissions (Woodhouse et al., 2013).

We have shown here that the role of organic oxidation products in new particle formation is particularly important in determining the indirect radiative effect of biogenic SOA. However, our understanding of which secondary organic species contribute to each stage of new particle formation and growth at different particle sizes is far from complete (e.g. Kulmala et al., 2013). In the absence of a detailed understanding, and bearing in mind computational costs, future model development regarding biogenic SOA could proceed on the basis that at least some (as yet undetermined) fraction of the secondary organic oxidation products contribute to new particle formation. Our simulations also highlight the important interaction between secondary organics and primary particles from combustion, particularly from fires in the tropics. This suggests that the (simulated) ageing of insoluble particles should be determined by the availability of condensable material, rather than prescribed (i.e. transferring insoluble particles to the soluble distribution after a fixed period of time), in order to capture the sensitivity of $\mathrm{CCN}$ concentration to changing levels of secondary organics.

Our results indicate that biogenic SOA very likely exerts a negative radiative effect in the present-day climate, via both the direct and first indirect effect, and that the magnitude of these effects is highly sensitive to our understanding of SOA 
yield and aerosol microphysical processes. Our work also reinforces the need to fully understand the influences of natural components on the Earth system in order to accurately determine the radiative effects of human activities.

Acknowledgements. C. E. Scott was supported by a Natural Environment Research Council (NERC) Doctoral Training Grant. A. Rap is funded by NERC grant NE/J004723/1. D. V. Spracklen is funded by NERC grant NE/G015015/1 and acknowledges support from the Bert Bolin Climate Center and the CLEO Project. P. M. Forster is funded by Engineering and Physical Sciences Research Council (EPSRC) grant EP/I014721/1 and K. S. Carslaw by the EC Seventh Framework Programme under grant agreement FP7-ENV-2010-265148 (Integrated Project PEGASOS). K. S. Carslaw and P. M. Forster are currently Royal Society Wolfson Merit Award holders. G. W. Mann and K. S. Carslaw are funded by the NERC National Centre for Atmospheric Science (NCAS). The Academy of Finland Centre of Excellence (FCoE) programme is acknowledged for supporting the observation programmes at Hyytiälä and Pallas (Project no. 1118615). The Swedish Environmental Agency (Naturvårdsverket) and Stockholm Environmental Protection Unit (Miljöförvaltningen) are acknowledged for providing financial support to the atmospheric observation programme at Aspvreten.

Edited by: S. M. Noe

\section{References}

Almeida, J., Schobesberger, S., Kurten, A., Ortega, I. K., Kupiainen-Maatta, O., Praplan, A. P., Adamov, A., Amorim, A., Bianchi, F., Breitenlechner, M., David, A., Dommen, J., Donahue, N. M., Downard, A., Dunne, E., Duplissy, J., Ehrhart, S., Flagan, R. C., Franchin, A., Guida, R., Hakala, J., Hansel, A., Heinritzi, M., Henschel, H., Jokinen, T., Junninen, H., Kajos, M., Kangasluoma, J., Keskinen, H., Kupc, A., Kurten, T., Kvashin, A. N., Laaksonen, A., Lehtipalo, K., Leiminger, M., Leppa, J., Loukonen, V., Makhmutov, V., Mathot, S., McGrath, M. J., Nieminen, T., Olenius, T., Onnela, A., Petaja, T., Riccobono, F., Riipinen, I., Rissanen, M., Rondo, L., Ruuskanen, T., Santos, F. D., Sarnela, N., Schallhart, S., Schnitzhofer, R., Seinfeld, J. H., Simon, M., Sipila, M., Stozhkov, Y., Stratmann, F., Tome, A., Trostl, J., Tsagkogeorgas, G., Vaattovaara, P., Viisanen, Y., Virtanen, A., Vrtala, A., Wagner, P. E., Weingartner, E., Wex, H., Williamson, C., Wimmer, D., Ye, P., Yli-Juuti, T., Carslaw, K. S., Kulmala, M., Curtius, J., Baltensperger, U., Worsnop, D. R., Vehkamaki, H., and Kirkby, J.: Molecular understanding of sulphuric acid-amine particle nucleation in the atmosphere, Nature, 502, 359-363, doi:10.1038/nature12663, 2013.

Andreae, M. O., Rosenfeld, D., Artaxo, P., Costa, A. A., Frank, G. P., Longo, K. M., and Silva-Dias, M. A. F.: Smoking Rain Clouds over the Amazon, Science, 303, 1337-1342, doi:10.1126/science.1092779, 2004.

Andres, R. J. and Kasgnoc, A. D.: A time-averaged inventory of subaerial volcanic sulfur emissions, J. Geophys. Res., 103, 25251-25261, doi:10.1029/98jd02091, 1998.

Arnold, S. R., Chipperfield, M. P., and Blitz, M. A.: A threedimensional model study of the effect of new temperature- dependent quantum yields for acetone photolysis, J. Geophys. Res., 110, D22305, doi:10.1029/2005jd005998, 2005.

Atkinson, R., Baulch, D. L., Cox, R. A., Hampson, R. F., Kerr, J. A., and Troe, J.: Evaluated Kinetic and Photochemical Data for Atmospheric Chemistry: Supplement III. IUPAC Subcommittee on Gas Kinetic Data Evaluation for Atmospheric Chemistry, J. Phys. Chem. Ref. Data, 18, 881-1097, doi:10.1063/1.555832, 1989.

Atkinson, R., Baulch, D. L., Cox, R. A., Crowley, J. N., Hampson, R. F., Hynes, R. G., Jenkin, M. E., Rossi, M. J., Troe, J., and IUPAC Subcommittee: Evaluated kinetic and photochemical data for atmospheric chemistry: Volume II - gas phase reactions of organic species, Atmos. Chem. Phys., 6, 3625-4055, doi:10.5194/acp-6-3625-2006, 2006.

Bala, G., Caldeira, K., Wickett, M., Phillips, T. J., Lobell, D. B., Delire, C., and Mirin, A.: Combined climate and carbon-cycle effects of large-scale deforestation, P. Natl. Acad. Sci. USA, 104, 6550-6555, doi:10.1073/pnas.0608998104, 2007.

Barahona, D., West, R. E. L., Stier, P., Romakkaniemi, S., Kokkola, H., and Nenes, A.: Comprehensively accounting for the effect of giant $\mathrm{CCN}$ in cloud activation parameterizations, Atmos. Chem. Phys., 10, 2467-2473, doi:10.5194/acp-10-2467-2010, 2010.

Bellouin, N., Mann, G. W., Woodhouse, M. T., Johnson, C., Carslaw, K. S., and Dalvi, M.: Impact of the modal aerosol scheme GLOMAP-mode on aerosol forcing in the Hadley Centre Global Environmental Model, Atmos. Chem. Phys., 13, 3027 3044, doi:10.5194/acp-13-3027-2013, 2013.

Betts, R. A.: Offset of the potential carbon sink from boreal forestation by decreases in surface albedo, Nature, 408, 187-190, doi:10.1038/35041545, 2000.

Bond, T. C., Streets, D. G., Yarber, K. F., Nelson, S. M., Woo, J.-H., and Klimont, Z.: A technology-based global inventory of black and organic carbon emissions from combustion, J. Geophys. Res., 109, D14203, doi:10.1029/2003jd003697, 2004.

Boy, M., Rannik, Ü., Lehtinen, K. E. J., Tarvainen, V., Hakola, H., and Kulmala, M.: Nucleation events in the continental boundary layer: Long-term statistical analyses of aerosol relevant characteristics, J. Geophys. Res., 108, 4667, doi:10.1029/2003jd003838, 2003.

Chang, R. Y.-W., Slowik, J. G., Shantz, N. C., Vlasenko, A., Liggio, J., Sjostedt, S. J., Leaitch, W. R., and Abbatt, J. P. D.: The hygroscopicity parameter $(\kappa)$ of ambient organic aerosol at a field site subject to biogenic and anthropogenic influences: relationship to degree of aerosol oxidation, Atmos. Chem. Phys., 10, 5047-5064, doi:10.5194/acp-10-5047-2010, 2010.

Chipperfield, M. P.: New version of the TOMCAT/SLIMCAT offline chemical transport model: Intercomparison of stratospheric tracer experiments, Q. J. Roy. Meteor. Soc., 132, 1179-1203, doi:10.1256/qj.05.51, 2006.

Claeys, M., Graham, B., Vas, G., Wang, W., Vermeylen, R., Pashynska, V., Cafmeyer, J., Guyon, P., Andreae, M. O., Artaxo, P., and Maenhaut, W.: Formation of Secondary Organic Aerosols Through Photooxidation of Isoprene, Science, 303, 1173-1176, doi:10.1126/science.1092805, 2004.

Cofala, J., Amann, M., Klimont, Z. S., and Schopp, W.: Scenarios of World Anthropogenic Emissions of $\mathrm{SO}_{2}, \mathrm{NO}_{\mathrm{x}}$ and $\mathrm{CO}$ up to 2030, in: Internal report of the Transboundary Air Pollution Programme, International Institute for Applied Systems Analysis, Laxenburg, Austria, 2005. 
Davin, E. L. and de Noblet-Ducoudré, N.: Climatic Impact of Global-Scale Deforestation: Radiative versus Nonradiative Processes, J. Climate, 23, 97-112, doi:10.1175/2009JCLI3102.1, 2010.

Delene, D. J. and Deshler, T.: Vertical profiles of cloud condensation nuclei above Wyoming, J. Geophys. Res.-Atmos., 106, 1257912588, doi:10.1029/2000jd900800, 2001.

Dentener, F., Kinne, S., Bond, T., Boucher, O., Cofala, J., Generoso, S., Ginoux, P., Gong, S., Hoelzemann, J. J., Ito, A., Marelli, L., Penner, J. E., Putaud, J.-P., Textor, C., Schulz, M., van der Werf, G. R., and Wilson, J.: Emissions of primary aerosol and precursor gases in the years 2000 and 1750 prescribed data-sets for AeroCom, Atmos. Chem. Phys., 6, 4321-4344, doi:10.5194/acp-64321-2006, 2006.

Duplissy, J., Gysel, M., Alfarra, M. R., Dommen, J., Metzger, A., Prevot, A. S. H., Weingartner, E., Laaksonen, A., Raatikainen, T., Good, N., Turner, S. F., McFiggans, G., and Baltensperger, U.: Cloud forming potential of secondary organic aerosol under near atmospheric conditions, Geophys. Res. Lett., 35, L03818, doi:10.1029/2007g1031075, 2008.

Dusek, U., Frank, G. P., Hildebrandt, L., Curtius, J., Schneider, J., Walter, S., Chand, D., Drewnick, F., Hings, S., Jung, D., Borrmann, S., and Andreae, M. O.: Size Matters More Than Chemistry for Cloud-Nucleating Ability of Aerosol Particles, Science, 312, 1375-1378, doi:10.1126/science.1125261, 2006.

Dusek, U., Frank, G. P., Curtius, J., Drewnick, F., Schneider, J., Kürten, A., Rose, D., Andreae, M. O., Borrmann, S., and Pöschl, U.: Enhanced organic mass fraction and decreased hygroscopicity of cloud condensation nuclei (CCN) during new particle formation events, Geophys. Res. Lett., 37, L03804, doi:10.1029/2009g1040930, 2010.

Edney, E. O., Kleindienst, T. E., Jaoui, M., Lewandowski, M., Offenberg, J. H., Wang, W., and Claeys, M.: Formation of 2methyl tetrols and 2-methylglyceric acid in secondary organic aerosol from laboratory irradiated isoprene/ $\mathrm{NO}_{\mathrm{X}} / \mathrm{SO}_{2} /$ air mixtures and their detection in ambient $\mathrm{PM}_{2.5}$ samples collected in the eastern United States, Atmos. Environ., 39, 5281-5289, doi:10.1016/j.atmosenv.2005.05.031, 2005.

Edwards, J. M. and Slingo, A.: Studies with a flexible new radiation code. I: Choosing a configuration for a large-scale model, Q. J. Roy. Meteor. Soc., 122, 689-719, doi:10.1002/qj.49712253107, 1996.

Engelhart, G. J., Asa-Awuku, A., Nenes, A., and Pandis, S. N.: CCN activity and droplet growth kinetics of fresh and aged monoterpene secondary organic aerosol, Atmos. Chem. Phys., 8, 39373949, doi:10.5194/acp-8-3937-2008, 2008.

Engelhart, G. J., Moore, R. H., Nenes, A., and Pandis, S. N.: Cloud condensation nuclei activity of isoprene secondary organic aerosol, J. Geophys. Res., 116, D02207, doi:10.1029/2010jd014706, 2011.

Fan, J., Zhang, R., Collins, D., and Li, G.: Contribution of secondary condensable organics to new particle formation: A case study in Houston, Texas, Geophys. Res. Lett., 33, L15802, doi:10.1029/2006g1026295, 2006.

Forster, P., Ramaswamy, V., Artaxo, P., Berntsen, T., Betts, R., Fahey, D. W., Haywood, J., Lean, J., Lowe, D. C., Myhre, G., Nganga, J., Prinn, R., Raga, G., Schulz, M., and Dorland, R. V.: Changes in Atmospheric Constituents and in Radiative Forcing, in: Climate Change 2007: The Physical Science Basis. Con- tribution of Working Group I to the Fourth Assessment Report of the Intergovernmental Panel on Climate Change, edited by: Solomon, S., Qin, D., Manning, M., Chen, Z., Marquis, M., Averyt, K. B., Tignor, M., and Miller, H. L., Cambridge University Press, Cambridge, UK and New York, USA, 2007.

Fountoukis, C. and Nenes, A.: Continued development of a cloud droplet formation parameterization for global climate models, J. Geophys. Res., 110, D11212, doi:10.1029/2004jd005591, 2005.

Fuchs, N. A. and Sutugin, A. G.: Highly dispersed aerosols, in: Topics in current aerosol research, Pergamin, New York, 1-60, 1971.

Goldstein, A. H. and Galbally, I. E.: Known and Unexplored Organic Constituents in the Earth's Atmosphere, Environ. Sci. Technol., 41, 1514-1521, doi:10.1021/es072476p, 2007.

Gong, S. L.: A parameterization of sea-salt aerosol source function for sub- and super-micron particles, Global Biogeochem. Cy., 17, 1097, doi:10.1029/2003gb002079, 2003.

Goto, D., Takemura, T., and Nakajima, T.: Importance of global aerosol modeling including secondary organic aerosol formed from monoterpene, J. Geophys. Res., 113, D07205, doi:10.1029/2007jd009019, 2008.

Griffin, R. J., Cocker III, D. R., Seinfeld, J. H., and Dabdub, D.: Estimate of Global Atmospheric Organic Aerosol from Oxidation of Biogenic Hydrocarbons, Geophys. Res. Lett., 26, 2721-2724, doi:10.1029/1999g1900476, 1999.

Guenther, A., Hewitt, C. N., Erickson, D., Fall, R., Geron, C., Graedel, T., Harley, P., Klinger, L., Lerdau, M., McKay, W. A., Pierce, T., Scholes, B., Steinbrecher, R., Tallamraju, R., Taylor, J., and Zimmerman, P.: A global model of natural volatile organic compound emissions, J. Geophys. Res., 100, 8873-8892, doi:10.1029/94jd02950, 1995.

Guibert, S., Snider, J. R., and Brenguier, J.-L.: Aerosol activation in marine stratocumulus clouds: 1 . Measurement validation for a closure study, J. Geophys. Res., 108, 8628, doi:10.1029/2002jd002678, 2003.

Gunthe, S. S., King, S. M., Rose, D., Chen, Q., Roldin, P., Farmer, D. K., Jimenez, J. L., Artaxo, P., Andreae, M. O., Martin, S. T., and Pöschl, U.: Cloud condensation nuclei in pristine tropical rainforest air of Amazonia: size-resolved measurements and modeling of atmospheric aerosol composition and $\mathrm{CCN}$ activity, Atmos. Chem. Phys., 9, 7551-7575, doi:10.5194/acp-9-75512009, 2009.

Halmer, M. M., Schmincke, H. U., and Graf, H. F.: The annual volcanic gas input into the atmosphere, in particular into the stratosphere: a global data set for the past 100 years, J. Volcanol. Geoth. Res., 115, 511-528, doi:10.1016/s0377-0273(01)003183, 2002.

Hatakeyama, S., Izumi, K., Fukuyama, T., and Akimoto, H.: Reactions of ozone with $\alpha$-pinene and $\beta$-pinene in air: Yields of gaseous and particulate products, J. Geophys. Res.-Atmos., 94, 13013-13024, doi:10.1029/JD094iD10p13013, 1989.

Hatakka, J., Aalto, T., Aaltonen, V., Aurela, M., Hakola, H., Komppula, M., Laurila, T., Lihavainen, H., Paatero, J., Salminen, K., and Viisanen, Y.: Overview of the atmospheric research activities and results at Pallas GAW station, Boreal Environ. Res., 8, 365-383, 2003.

Heald, C. L., Henze, D. K., Horowitz, L. W., Feddema, J., Lamarque, J. F., Guenther, A., Hess, P. G., Vitt, F., Seinfeld, J. H., Goldstein, A. H., and Fung, I.: Predicted change in global secondary organic aerosol concentrations in response to future climate, 
emissions, and land use change, J. Geophys. Res., 113, D05211, doi:10.1029/2007jd009092, 2008.

Heald, C. L., Wilkinson, M. J., Monson, R. K., Alo, C. A., Wang, G., and Guenther, A.: Response of isoprene emission to ambient $\mathrm{CO} 2$ changes and implications for global budgets, Glob. Change Biol., 15, 1127-1140, doi:10.1111/j.1365-2486.2008.01802.x, 2009.

Heald, C. L., Ridley, D. A., Kreidenweis, S. M., and Drury, E. E.: Satellite observations cap the atmospheric organic aerosol budget, Geophys. Res. Lett., 37, L24808, doi:10.1029/2010g1045095, 2010.

Heald, C. L., Coe, H., Jimenez, J. L., Weber, R. J., Bahreini, R., Middlebrook, A. M., Russell, L. M., Jolleys, M., Fu, T.-M., Allan, J. D., Bower, K. N., Capes, G., Crosier, J., Morgan, W. T., Robinson, N. H., Williams, P. I., Cubison, M. J., DeCarlo, P. F., and Dunlea, E. J.: Exploring the vertical profile of atmospheric organic aerosol: comparing 17 aircraft field campaigns with a global model, Atmos. Chem. Phys., 11, 12673-12696, doi:10.5194/acp-11-12673-2011, 2011.

Hoyle, C. R., Boy, M., Donahue, N. M., Fry, J. L., Glasius, M., Guenther, A., Hallar, A. G., Huff Hartz, K., Petters, M. D., Petäjä, T., Rosenoern, T., and Sullivan, A. P.: A review of the anthropogenic influence on biogenic secondary organic aerosol, Atmos. Chem. Phys., 11, 321-343, doi:10.5194/acp-11-321-2011, 2011.

Hudson, J. G. and Frisbie, P. R.: Surface cloud condensation nuclei and condensation nuclei measurements at Reno, Nevada, Atmos. Environ. A-Gen., 25, 2285-2299, doi:10.1016/09601686(91)90104-F, 1991.

Jimenez, J. L., Canagaratna, M. R., Donahue, N. M., Prevot, A. S. H., Zhang, Q., Kroll, J. H., DeCarlo, P. F., Allan, J. D., Coe, H., Ng, N. L., Aiken, A. C., Docherty, K. S., Ulbrich, I. M., Grieshop, A. P., Robinson, A. L., Duplissy, J., Smith, J. D., Wilson, K. R., Lanz, V. A., Hueglin, C., Sun, Y. L., Tian, J., Laaksonen, A., Raatikainen, T., Rautiainen, J., Vaattovaara, P., Ehn, M., Kulmala, M., Tomlinson, J. M., Collins, D. R., Cubison, M. J., E., Dunlea, J., Huffman, J. A., Onasch, T. B., Alfarra, M. R., Williams, P. I., Bower, K., Kondo, Y., Schneider, J., Drewnick, F., Borrmann, S., Weimer, S., Demerjian, K., Salcedo, D., Cottrell, L., Griffin, R., Takami, A., Miyoshi, T., Hatakeyama, S., Shimono, A., Sun, J. Y., Zhang, Y. M., Dzepina, K., Kimmel, J. R., Sueper, D., Jayne, J. T., Herndon, S. C., Trimborn, A. M., Williams, L. R., Wood, E. C., Middlebrook, A. M., Kolb, C. E., Baltensperger, U., and Worsnop, D. R.: Evolution of Organic Aerosols in the Atmosphere, Science, 326, 1525-1529, doi:10.1126/science.1180353, 2009.

Kanakidou, M., Seinfeld, J. H., Pandis, S. N., Barnes, I., Dentener, F. J., Facchini, M. C., Van Dingenen, R., Ervens, B., Nenes, A., Nielsen, C. J., Swietlicki, E., Putaud, J. P., Balkanski, Y., Fuzzi, S., Horth, J., Moortgat, G. K., Winterhalter, R., Myhre, C. E. L., Tsigaridis, K., Vignati, E., Stephanou, E. G., and Wilson, J.: Organic aerosol and global climate modelling: a review, Atmos. Chem. Phys., 5, 1053-1123, doi:10.5194/acp-5-1053-2005, 2005.

Kanawade, V. P., Jobson, B. T., Guenther, A. B., Erupe, M. E., Pressley, S. N., Tripathi, S. N., and Lee, S.-H.: Isoprene suppression of new particle formation in a mixed deciduous forest, Atmos. Chem. Phys., 11, 6013-6027, doi:10.5194/acp-11-60132011,2011
Kavouras, I. G., Mihalopoulos, N., and Stephanou, E. G.: Formation of atmospheric particles from organic acids produced by forests, Nature, 395, 683-686, doi:10.1038/27179, 1998.

Kavouras, I. G., Mihalopoulos, N., and Stephanou, E. G.: Formation and gas/particle partitioning of monoterpenes photooxidation products over forests, Geophys. Res. Lett., 26, 55-58, doi:10.1029/1998g1900251, 1999.

Kerminen, V.-M. and Kulmala, M.: Analytical formulae connecting the "real" and the "apparent" nucleation rate and the nuclei number concentration for atmospheric nucleation events, J. Aerosol Sci., 33, 609-622, doi:10.1016/s0021-8502(01)00194-x, 2002.

Kettle, A. J. and Andreae, M. O.: Flux of dimethylsulfide from the oceans: A comparison of updated data sets and flux models, J. Geophys. Res.-Atmos., 105, 26793-26808, doi:10.1029/2000jd900252, 2000.

Kiendler-Scharr, A., Wildt, J., Maso, M. D., Hohaus, T., Kleist, E., Mentel, T. F., Tillmann, R., Uerlings, R., Schurr, U., and Wahner, A.: New particle formation in forests inhibited by isoprene emissions, Nature, 461, 381-384, doi:10.1038/nature08292, 2009.

King, S. M., Rosenoern, T., Shilling, J. E., Chen, Q., Wang, Z., Biskos, G., McKinney, K. A., Pöschl, U., and Martin, S. T.: Cloud droplet activation of mixed organic-sulfate particles produced by the photooxidation of isoprene, Atmos. Chem. Phys., 10, 3953-3964, doi:10.5194/acp-10-3953-2010, 2010.

Komppula, M., Lihavainen, H., Hatakka, J., Paatero, J., Aalto, P., Kulmala, M., and Viisanen, Y.: Observations of new particle formation and size distributions at two different heights and surroundings in subarctic area in northern Finland, J. Geophys. Res.Atmos., 108, 4295, doi:10.1029/2002jd002939, 2003.

Kroll, J. H., Ng, N. L., Murphy, S. M., Flagan, R. C., and Seinfeld, J. H.: Secondary organic aerosol formation from isoprene photooxidation under high- $\mathrm{NO}_{\mathrm{x}}$ conditions, Geophys. Res. Lett., 32, L18808, doi:10.1029/2005g1023637, 2005.

Kroll, J. H., Ng, N. L., Murphy, S. M., Flagan, R. C., and Seinfeld, J. H.: Secondary Organic Aerosol Formation from Isoprene Photooxidation, Environ. Sci. Technol., 40, 1869-1877, doi:10.1021/es0524301, 2006.

Kulmala, M., Laaksonen, A., and Pirjola, L.: Parameterisations for sulphuric acid / water nucleation rates, J. Geophys. Res.-Atmos., 103, 8301-8307, doi:10.1029/97JD03718, 1998a.

Kulmala, M., Toivonen, A., Mäkelä, J. M., and Laaksonen, A.: Analysis of the growth of nucleation mode particles observed in Boreal forest, Tellus B, 50, 449-462, doi:10.1034/j.16000889.1998.t01-4-00004.x, 1998b.

Kulmala, M., Hämeri, K., Aalto, P. P., Mäkelä, J. M., Pirjola, L., Nilsson, E. D., Buzorius, G., Rannik, Ü., Maso, M. D., Seidl, W., Hoffman, T., Janson, R., Hansson, H.-C., Viisanen, Y., Laaksonen, A., and O'Dowd, C. D.: Overview of the international project on biogenic aerosol formation in the boreal forest (BIOFOR), Tellus B, 53, 324-343, doi:10.1034/j.16000889.2001.530402.x, 2001a.

Kulmala, M., Maso, M. D., Mäkelä, J. M., Pirjola, L., Väkevä, M., Aalto, P., Miikkulainen, P., Hämeri, K., and O'Dowd, C. D.: On the formation, growth and composition of nucleation mode particles, Tellus B, 53, 479-490, doi:10.1034/j.16000889.2001.530411.x, 2001b.

Kulmala, M., Suni, T., Lehtinen, K. E. J., Dal Maso, M., Boy, M., Reissell, A., Rannik, Ü., Aalto, P., Keronen, P., Hakola, H., Bäck, J., Hoffmann, T., Vesala, T., and Hari, P.: A new feedback 
mechanism linking forests, aerosols, and climate, Atmos. Chem. Phys., 4, 557-562, doi:10.5194/acp-4-557-2004, 2004.

Kulmala, M., Lehtinen, K. E. J., and Laaksonen, A.: Cluster activation theory as an explanation of the linear dependence between formation rate of $3 \mathrm{~nm}$ particles and sulphuric acid concentration, Atmos. Chem. Phys., 6, 787-793, doi:10.5194/acp-6-787-2006, 2006.

Kulmala, M., Kontkanen, J., Junninen, H., Lehtipalo, K., Manninen, H. E., Nieminen, T., Petäjä, T., Sipilä, M., Schobesberger, S., Rantala, P., Franchin, A., Jokinen, T., Järvinen, E., Äijälä, M., Kangasluoma, J., Hakala, J., Aalto, P. P., Paasonen, P., Mikkilä, J., Vanhanen, J., Aalto, J., Hakola, H., Makkonen, U., Ruuskanen, T., Mauldin, R. L., Duplissy, J., Vehkamäki, H., Bäck, J., Kortelainen, A., Riipinen, I., Kurtén, T., Johnston, M. V., Smith, J. N., Ehn, M., Mentel, T. F., Lehtinen, K. E. J., Laaksonen, A., Kerminen, V.-M., and Worsnop, D. R.: Direct Observations of Atmospheric Aerosol Nucleation, Science, 339, 943946, doi:10.1126/science.1227385, 2013

Kurten, T., Kulmala, M., Maso, M. D., Suni, T., Reissell, A., Vehkamaki, H., Hari, P., Laaksonen, A., Viisanen, Y., and Vesala, T.: Estimation of different forest-related contributions to the radiative balance using observations in southern Finland, Boreal Environ. Res., 8, 275-285, 2003.

Laaksonen, A., Kulmala, M., O’Dowd, C. D., Joutsensaari, J., Vaattovaara, P., Mikkonen, S., Lehtinen, K. E. J., Sogacheva, L., Dal Maso, M., Aalto, P., Petäjä, T., Sogachev, A., Yoon, Y. J., Lihavainen, H., Nilsson, D., Facchini, M. C., Cavalli, F., Fuzzi, S., Hoffmann, T., Arnold, F., Hanke, M., Sellegri, K., Umann, B., Junkermann, W., Coe, H., Allan, J. D., Alfarra, M. R., Worsnop, D. R., Riekkola, M. -L., Hyötyläinen, T., and Viisanen, Y.: The role of VOC oxidation products in continental new particle formation, Atmos. Chem. Phys., 8, 2657-2665, doi:10.5194/acp-82657-2008, 2008.

Lathière, J., Hauglustaine, D. A., De Noblet-Ducoudré, N., Krinner, G., and Folberth, G. A.: Past and future changes in biogenic volatile organic compound emissions simulated with a global dynamic vegetation model, Geophys. Res. Lett., 32, L20818, doi:10.1029/2005g1024164, 2005.

Lee, L. A., Carslaw, K. S., Pringle, K. J., and Mann, G. W.: Mapping the uncertainty in global CCN using emulation, Atmos. Chem. Phys., 12, 9739-9751, doi:10.5194/acp-12-9739-2012, 2012.

Lee, L. A., Pringle, K. J., Reddington, C. L., Mann, G. W., Stier, P., Spracklen, D. V., Pierce, J. R., and Carslaw, K. S.: The magnitude and causes of uncertainty in global model simulations of cloud condensation nuclei, Atmos. Chem. Phys., 13, 8879-8914, doi:10.5194/acp-13-8879-2013, 2013.

Lihavainen, H., Kerminen, V.-M., Tunved, P., Aaltonen, V., Arola, A., Hatakka, J., Hyvärinen, A., and Viisanen, Y.: Observational signature of the direct radiative effect by natural boreal forest aerosols and its relation to the corresponding first indirect effect, J. Geophys. Res., 114, D20206, doi:10.1029/2009jd012078, 2009.

Makkonen, R., Asmi, A., Kerminen, V.-M., Boy, M., Arneth, A., Guenther, A., and Kulmala, M.: BVOC-aerosol-climate interactions in the global aerosol-climate model ECHAM5.5-HAM2, Atmos. Chem. Phys., 12, 10077-10096, doi:10.5194/acp-1210077-2012, 2012.

Mann, G. W., Carslaw, K. S., Spracklen, D. V., Ridley, D. A., Manktelow, P. T., Chipperfield, M. P., Pickering, S. J., and
Johnson, C. E.: Description and evaluation of GLOMAP-mode: a modal global aerosol microphysics model for the UKCA composition-climate model, Geosci. Model Dev., 3, 519-551, doi:10.5194/gmd-3-519-2010, 2010.

Mann, G. W., Carslaw, K. S., Ridley, D. A., Spracklen, D. V., Pringle, K. J., Merikanto, J., Korhonen, H., Schwarz, J. P., Lee, L. A., Manktelow, P. T., Woodhouse, M. T., Schmidt, A., Breider, T. J., Emmerson, K. M., Reddington, C. L., Chipperfield, M. P., and Pickering, S. J.: Intercomparison of modal and sectional aerosol microphysics representations within the same 3-D global chemical transport model, Atmos. Chem. Phys., 12, 4449-4476, doi:10.5194/acp-12-4449-2012, 2012.

Merikanto, J., Spracklen, D. V., Mann, G. W., Pickering, S. J., and Carslaw, K. S.: Impact of nucleation on global CCN, Atmos. Chem. Phys., 9, 8601-8616, doi:10.5194/acp-9-8601-2009, 2009.

Metzger, A., Verheggen, B., Dommen, J., Duplissy, J., Prevot, A. S. H., Weingartner, E., Riipinen, I., Kulmala, M., Spracklen, D. V., Carslaw, K. S., and Baltensperger, U.: Evidence for the role of organics in aerosol particle formation under atmospheric conditions, P. Natl. Acad. Sci. USA, 107, 6646-6651, doi:10.1073/pnas.0911330107, 2010.

Nenes, A. and Seinfeld, J. H.: Parameterization of cloud droplet formation in global climate models, J. Geophys. Res., 108, 4415, doi:10.1029/2002JD002911, 2003.

O'Donnell, D., Tsigaridis, K., and Feichter, J.: Estimating the direct and indirect effects of secondary organic aerosols using ECHAM5-HAM, Atmos. Chem. Phys., 11, 8635-8659, doi:10.5194/acp-11-8635-2011, 2011.

O'Dowd, C. D., Aalto, P., Hmeri, K., Kulmala, M., and Hoffmann, T.: Aerosol formation: Atmospheric particles from organic vapours, Nature, 416, 497-498, doi:10.1038/416497a, 2002.

Paasonen, P., Nieminen, T., Asmi, E., Manninen, H. E., Petäjä, T., Plass-Dülmer, C., Flentje, H., Birmili, W., Wiedensohler, A., Hõrrak, U., Metzger, A., Hamed, A., Laaksonen, A., Facchini, M. C., Kerminen, V.-M., and Kulmala, M.: On the roles of sulphuric acid and low-volatility organic vapours in the initial steps of atmospheric new particle formation, Atmos. Chem. Phys., 10, 11223-11242, doi:10.5194/acp-10-11223-2010, 2010.

Paasonen, P., Asmi, A., Petäjä, T., Kajos, M. K., Äijälä, M., Junninen, H., Holst, T., Abbatt, J. P. D., Arneth, A., Birmili, W., van der Gon, H. D., Hamed, A., Hoffer, A., Laakso, L., Laaksonen, A., Richard Leaitch, W., Plass-Dülmer, C., Pryor, S. C., Räisänen, P., Swietlicki, E., Wiedensohler, A., Worsnop, D. R., Kerminen, V.-M., and Kulmala, M.: Warming-induced increase in aerosol number concentration likely to moderate climate change, Nat. Geosci., 6, 438-442, doi:10.1038/ngeo1800, 2013.

Pacifico, F., Folberth, G. A., Jones, C. D., Harrison, S. P., and Collins, W. J.: Sensitivity of biogenic isoprene emissions to past, present, and future environmental conditions and implications for atmospheric chemistry, J. Geophys. Res., 117, D22302, doi:10.1029/2012jd018276, 2012.

Peng, Y., Lohmann, U., and Leaitch, R.: Importance of vertical velocity variations in the cloud droplet nucleation process of marine stratus clouds, J. Geophys. Res., 110, D21213, doi:10.1029/2004jd004922, 2005.

Penner, J. E., Andreae, M., Annegarn, H., Barrie, L., Feichter, J., Hegg, D., Jayaraman, A., Leaitch, R., Murphy, D., Nganga, J., and Pitari, G.: Aerosols, their Direct and Indirect Effects, in: 
Climate Change 2001: The Physical Science Basis. Contribution of Working Group I to the Third Assessment Report of the Intergovernmental Panel on Climate Change, edited by: Houghton, J. T., Ding, Y., Griggs, D. J., Noguer, M., van der Linden, P. J., Dai, X., Maskell, K., and Johnson, C. A., Cambridge University Press, Cambridge, UK and New York, USA, 2001.

Petters, M. D. and Kreidenweis, S. M.: A single parameter representation of hygroscopic growth and cloud condensation nucleus activity, Atmos. Chem. Phys., 7, 1961-1971, doi:10.5194/acp-71961-2007, 2007.

Pierce, J. R. and Adams, P. J.: Uncertainty in global CCN concentrations from uncertain aerosol nucleation and primary emission rates, Atmos. Chem. Phys., 9, 1339-1356, doi:10.5194/acp-91339-2009, 2009.

Pierce, J. R., Riipinen, I., Kulmala, M., Ehn, M., Petäjä, T., Junninen, H., Worsnop, D. R., and Donahue, N. M.: Quantification of the volatility of secondary organic compounds in ultrafine particles during nucleation events, Atmos. Chem. Phys., 11, 90199036, doi:10.5194/acp-11-9019-2011, 2011.

Pierce, J. R., Leaitch, W. R., Liggio, J., Westervelt, D. M., Wainwright, C. D., Abbatt, J. P. D., Ahlm, L., Al-Basheer, W., Cziczo, D. J., Hayden, K. L., Lee, A. K. Y., Li, S.-M., Russell, L. M., Sjostedt, S. J., Strawbridge, K. B., Travis, M., Vlasenko, A., Wentzell, J. J. B., Wiebe, H. A., Wong, J. P. S., and Macdonald, A. M.: Nucleation and condensational growth to $\mathrm{CCN}$ sizes during a sustained pristine biogenic SOA event in a forested mountain valley, Atmos. Chem. Phys., 12, 3147-3163, doi:10.5194/acp-12-3147-2012, 2012.

Pringle, K. J., Carslaw, K. S., Spracklen, D. V., Mann, G. M., and Chipperfield, M. P.: The relationship between aerosol and cloud drop number concentrations in a global aerosol microphysics model, Atmos. Chem. Phys., 9, 4131-4144, doi:10.5194/acp-94131-2009, 2009.

Pringle, K. J., Carslaw, K. S., Fan, T., Mann, G.W., Hill, A., Stier, P., Zhang, K., and Tost, H.: A multi-model assessment of the impact of sea spray geoengineering on cloud droplet number, Atmos. Chem. Phys., 12, 11647-11663, doi:10.5194/acp-1211647-2012, 2012.

Pye, H. O. T. and Seinfeld, J. H.: A global perspective on aerosol from low-volatility organic compounds, Atmos. Chem. Phys., 10, 4377-4401, doi:10.5194/acp-10-4377-2010, 2010.

Rap, A., Scott, C. E., Spracklen, D. V., Bellouin, N., Forster, P. M., Carslaw, K. S., Schmidt, A., and Mann, G.: Natural aerosol direct and indirect radiative effects, Geophys. Res. Lett., 40, $3297-$ 3301, doi:10.1002/grl.50441, 2013.

Reddington, C. L., Carslaw, K. S., Spracklen, D. V., Frontoso, M. G., Collins, L., Merikanto, J., Minikin, A., Hamburger, T., Coe, H., Kulmala, M., Aalto, P., Flentje, H., Plass-Dülmer, C., Birmili, W., Wiedensohler, A., Wehner, B., Tuch, T., Sonntag, A., O’Dowd, C. D., Jennings, S. G., Dupuy, R., Baltensperger, U., Weingartner, E., Hansson, H.-C., Tunved, P., Laj, P., Sellegri, K., Boulon, J., Putaud, J.-P., Gruening, C., Swietlicki, E., Roldin, P., Henzing, J. S., Moerman, M., Mihalopoulos, N., Kouvarakis, G., Ždímal, V., Zíková, N., Marinoni, A., Bonasoni, P., and Duchi, R.: Primary versus secondary contributions to particle number concentrations in the European boundary layer, Atmos. Chem. Phys., 11, 12007-12036, doi:10.5194/acp-11-12007-2011, 2011.

Riccobono, F., Rondo, L., Sipilä, M., Barmet, P., Curtius, J., Dommen, J., Ehn, M., Ehrhart, S., Kulmala, M., Kürten, A., Mikkilä,
J., Paasonen, P., Petäjä, T., Weingartner, E., and Baltensperger, U.: Contribution of sulfuric acid and oxidized organic compounds to particle formation and growth, Atmos. Chem. Phys., 12, 9427-9439, doi:10.5194/acp-12-9427-2012, 2012.

Riipinen, I., Pierce, J. R., Yli-Juuti, T., Nieminen, T., Häkkinen, S., Ehn, M., Junninen, H., Lehtipalo, K., Petäjä, T., Slowik, J., Chang, R., Shantz, N. C., Abbatt, J., Leaitch, W. R., Kerminen, V.-M., Worsnop, D. R., Pandis, S. N., Donahue, N. M., and Kulmala, M.: Organic condensation: a vital link connecting aerosol formation to cloud condensation nuclei (CCN) concentrations, Atmos. Chem. Phys., 11, 3865-3878, doi:10.5194/acp-11-38652011, 2011.

Riipinen, I., Yli-Juuti, T., Pierce, J. R., Petäjä, T., Worsnop, D. R., Kulmala, M., and Donahue, N. M.: The contribution of organics to atmospheric nanoparticle growth, Nat. Geosci., 5, 453-458, doi:10.1038/ngeo1499, 2012.

Roberts, G. C., Andreae, M. O., Zhou, J., and Artaxo, P.: Cloud condensation nuclei in the Amazon Basin: "marine" conditions over a continent?, Geophys. Res. Lett., 28, 2807-2810, doi:10.1029/2000g1012585, 2001.

Robinson, N. H., Hamilton, J. F., Allan, J. D., Langford, B., Oram, D. E., Chen, Q., Docherty, K., Farmer, D. K., Jimenez, J. L., Ward, M. W., Hewitt, C. N., Barley, M. H., Jenkin, M. E., Rickard, A. R., Martin, S. T., McFiggans, G., and Coe, H.: Evidence for a significant proportion of Secondary Organic Aerosol from isoprene above a maritime tropical forest, Atmos. Chem. Phys., 11, 1039-1050, doi:10.5194/acp-11-1039-2011, 2011.

Rossow, W. B. and Schiffer, R. A.: Advances in Understanding Clouds from ISCCP, B. Am. Meteorol. Soc., 80, 2261-2287, 1999.

Schmidt, A., Carslaw, K. S., Mann, G. W., Rap, A., Pringle, K. J., Spracklen, D. V., Wilson, M., and Forster, P. M.: Importance of tropospheric volcanic aerosol for indirect radiative forcing of climate, Atmos. Chem. Phys., 12, 7321-7339, doi:10.5194/acp-127321-2012, 2012.

Scott, C. E., Spracklen, D. V., Pierce, J. R., Riipinen, I., D’Andrea, S. D., Rap, A., Carslaw, K. S., Forster, P. M., Kulmala, M., Mann, G. W., and Pringle, K.: Impact of partitioning approach on the indirect radiative effect of biogenic secondary organic aerosol, in preparation, 2014.

Shilling, J. E., Chen, Q., King, S. M., Rosenoern, T., Kroll, J. H., Worsnop, D. R., DeCarlo, P. F., Aiken, A. C., Sueper, D., Jimenez, J. L., and Martin, S. T.: Loading-dependent elemental composition of $\alpha$-pinene SOA particles, Atmos. Chem. Phys., 9, 771-782, doi:10.5194/acp-9-771-2009, 2009.

Sihto, S.-L., Kulmala, M., Kerminen, V.-M., Dal Maso, M., Petäjä, T., Riipinen, I., Korhonen, H., Arnold, F., Janson, R., Boy, M., Laaksonen, A., and Lehtinen, K. E. J.: Atmospheric sulphuric acid and aerosol formation: implications from atmospheric measurements for nucleation and early growth mechanisms, Atmos. Chem. Phys., 6, 4079-4091, doi:10.5194/acp-6-4079-2006, 2006.

Smith, J. N., Dunn, M. J., VanReken, T. M., Iida, K., Stolzenburg, M. R., McMurry, P. H., and Huey, L. G.: Chemical composition of atmospheric nanoparticles formed from nucleation in Tecamac, Mexico: Evidence for an important role for organic species in nanoparticle growth, Geophys. Res. Lett., 35, L04808, doi:10.1029/2007g1032523, 2008. 
Snyder, P. K., Delire, C., and Foley, J. A.: Evaluating the influence of different vegetation biomes on the global climate, Clim. Dynam., 23, 279-302, doi:10.1007/s00382-004-0430-0, 2004.

Spracklen, D. V., Pringle, K. J., Carslaw, K. S., Chipperfield, M. P., and Mann, G. W.: A global off-line model of sizeresolved aerosol microphysics: I. Model development and prediction of aerosol properties, Atmos. Chem. Phys., 5, 22272252, doi:10.5194/acp-5-2227-2005, 2005a.

Spracklen, D. V., Pringle, K. J., Carslaw, K. S., Chipperfield, M. P., and Mann, G. W.: A global off-line model of size-resolved aerosol microphysics: II. Identification of key uncertainties, Atmos. Chem. Phys., 5, 3233-3250, doi:10.5194/acp-5-3233-2005, 2005b.

Spracklen, D. V., Carslaw, K. S., Kulmala, M., Kerminen, V.-M., Mann, G. W., and Sihto, S.-L.: The contribution of boundary layer nucleation events to total particle concentrations on regional and global scales, Atmos. Chem. Phys., 6, 5631-5648, doi:10.5194/acp-6-5631-2006, 2006.

Spracklen, D. V., Bonn, B., and Carslaw, K. S.: Boreal forests, aerosols and the impacts on clouds and climate, Philos. T. R. Soc. A, 366, 4613-4626, doi:10.1098/rsta.2008.0201, 2008a.

Spracklen, D. V., Carslaw, K. S., Kulmala, M., Kerminen, V.-M., Sihto, S.-L., Riipinen, I., Merikanto, J., Mann, G. W., Chipperfield, M. P., Wiedensohler, A., Birmili, W., and Lihavainen, $\mathrm{H}$.: Contribution of particle formation to global cloud condensation nuclei concentrations, Geophys. Res. Lett., 35, L06808, doi:10.1029/2007g1033038, 2008b.

Spracklen, D. V., Carslaw, K. S., Pöschl, U., Rap, A., and Forster, P. M.: Global cloud condensation nuclei influenced by carbonaceous combustion aerosol, Atmos. Chem. Phys., 11, 9067-9087, doi:10.5194/acp-11-9067-2011, 2011a.

Spracklen, D. V., Jimenez, J. L., Carslaw, K. S., Worsnop, D. R., Evans, M. J., Mann, G. W., Zhang, Q., Canagaratna, M. R., Allan, J., Coe, H., McFiggans, G., Rap, A., and Forster, P.: Aerosol mass spectrometer constraint on the global secondary organic aerosol budget, Atmos. Chem. Phys., 11, 12109-12136, doi:10.5194/acp-11-12109-2011, $2011 \mathrm{~b}$.

Stier, P., Feichter, J., Kinne, S., Kloster, S., Vignati, E., Wilson, J., Ganzeveld, L., Tegen, I., Werner, M., Balkanski, Y., Schulz, M., Boucher, O., Minikin, A., and Petzold, A.: The aerosol-climate model ECHAM5-HAM, Atmos. Chem. Phys., 5, 1125-1156, doi:10.5194/acp-5-1125-2005, 2005.

Tunved, P., Korhonen, H., Ström, J., Hansson, H.-C., Lehtinen, K. E. J., and Kulmala, M.: A pseudo-Lagrangian model study of the size distribution properties over Scandinavia: transport from Aspvreten to Värriö, Atmos. Chem. Phys. Discuss., 4, 7757-7794, doi:10.5194/acpd-4-7757-2004, 2004a.

Tunved, P., Ström, J., and Hansson, H.-C.: An investigation of processes controlling the evolution of the boundary layer aerosol size distribution properties at the Swedish background station Aspvreten, Atmos. Chem. Phys., 4, 2581-2592, doi:10.5194/acp-4-2581-2004, 2004b.

Tunved, P., Hansson, H.-C., Kerminen, V.-M., Strom, J., Maso, M. D., Lihavainen, H., Viisanen, Y., Aalto, P. P., Komppula, M., and Kulmala, M.: High Natural Aerosol Loading over Boreal Forests, Science, 312, 261-263, doi:10.1126/science.1123052, 2006.

Tunved, P., Ström, J., Kulmala, M., Kerminen, V.-M., Dal Maso, M., Svenningson, B., Lunder, C., and Hansson, H.-C.: The natural aerosol over Northern Europe and its relation to anthropogenic emissions - implications of important climate feedbacks, Tellus B, 60, 473-484, doi:10.1111/j.1600-0889.2008.00363.x, 2008.

Twomey, S.: Influence of Pollution on Shortwave Albedo Clouds, J. Atmos. Sci., 34, 1149-1152, 1977.

van der Werf, G. R., Randerson, J. T., Collatz, G. J., Giglio, L., Kasibhatla, P. S., Arellano, A. F., Olsen, S. C., and Kasischke, E. S.: Continental-Scale Partitioning of Fire Emissions During the 1997 to 2001 El Niño/La Niña Period, Science, 303, 73-76, doi:10.1126/science.1090753, 2004.

Verheggen, B., Mozurkewich, M., Caffrey, P., Frick, G., Hoppel, W., and Sullivan, W.: $\alpha$-Pinene Oxidation in the Presence of Seed Aerosol: Estimates of Nucleation Rates, Growth Rates, and Yield, Environ. Sci. Technol., 41, 6046-6051, doi:10.1021/es070245c, 2007.

Vestin, A., Rissler, J., Swietlicki, E., Frank, G. P., and Andreae, M. O.: Cloud-nucleating properties of the Amazonian biomass burning aerosol: Cloud condensation nuclei measurements and modeling, J. Geophys. Res.-Atmos., 112, D14201, doi:10.1029/2006jd008104, 2007.

Wang, J., Lee, Y.-N., Daum, P. H., Jayne, J., and Alexander, M. L.: Effects of aerosol organics on cloud condensation nucleus $(\mathrm{CCN})$ concentration and first indirect aerosol effect, Atmos. Chem. Phys., 8, 6325-6339, doi:10.5194/acp-8-6325-2008, 2008.

Williams, E., Rosenfeld, D., Madden, N., Gerlach, J., Gears, N., Atkinson, L., Dunnemann, N., Frostrom, G., Antonio, M., Biazon, B., Camargo, R., Franca, H., Gomes, A., Lima, M., Machado, R., Manhaes, S., Nachtigall, L., Piva, H., Quintiliano, W., Machado, L., Artaxo, P., Roberts, G., Renno, N., Blakeslee, R., Bailey, J., Boccippio, D., Betts, A., Wolff, D., Roy, B., Halverson, J., Rickenbach, T., Fuentes, J., and Avelino, E.: Contrasting convective regimes over the Amazon: Implications for cloud electrification, J. Geophys. Res.-Atmos., 107, 8082, doi:10.1029/2001jd000380, 2002.

Woodhouse, M. T., Mann, G. W., Carslaw, K. S., and Boucher, O.: Sensitivity of cloud condensation nuclei to regional changes in dimethyl-sulphide emissions, Atmos. Chem. Phys., 13, 2723 2733, doi:10.5194/acp-13-2723-2013, 2013.

Yli-Juuti, T., Nieminen, T., Hirsikko, A., Aalto, P. P., Asmi, E., Hõrrak, U., Manninen, H. E., Patokoski, J., Dal Maso, M., Petäjä, T., Rinne, J., Kulmala, M., and Riipinen, I.: Growth rates of nucleation mode particles in Hyytiälä during 20032009: variation with particle size, season, data analysis method and ambient conditions, Atmos. Chem. Phys., 11, 12865-12886, doi:10.5194/acp-11-12865-2011, 2011.

Yu, J., Cocker, D. R., Griffin, R. J., Flagan, R. C., and Seinfeld, J. H.: Gas-Phase Ozone Oxidation of Monoterpenes: Gaseous and Particulate Products, J. Atmos. Chem., 34, 207 258, doi:10.1023/a:1006254930583, 1999a.

Yu, J., Griffin, R. J., Cocker III, D. R., Flagan, R. C., Seinfeld, J. H., and Blanchard, P.: Observation of Gaseous and Particulate Products of Monoterpene Oxidation in Forest Atmospheres, Geophys Res. Lett., 26, 1145-1148, doi:10.1029/1999g1900169, 1999 b.

Zhang, Q., Jimenez, J. L., Canagaratna, M. R., Allan, J. D., Coe, H., Ulbrich, I., Alfarra, M. R., Takami, A., Middlebrook, A. M., Sun, Y. L., Dzepina, K., Dunlea, E., Docherty, K., DeCarlo, P. F., Salcedo, D., Onasch, T., Jayne, J. T., Miyoshi, T., Shimono, A., Hatakeyama, S., Takegawa, N., Kondo, Y., Schneider, J., Drewnick, F., Borrmann, S., Weimer, S., Demerjian, K., Williams, P., Bower, K., Bahreini, R., Cottrell, L., 
Griffin, R. J., Rautiainen, J., Sun, J. Y., Zhang, Y. M., and Worsnop, D. R.: Ubiquity and dominance of oxygenated species in organic aerosols in anthropogenically-influenced Northern Hemisphere midlatitudes, Geophys. Res. Lett., 34, L13801, doi:10.1029/2007GL029979, 2007.
Zhang, R., Wang, L., Khalizov, A. F., Zhao, J., Zheng, J., McGraw, R. L., and Molina, L. T.: Formation of nanoparticles of blue haze enhanced by anthropogenic pollution, P. Natl. Acad. Sci. USA, 106, 17650-17654, doi:10.1073/pnas.0910125106, 2009. 